ANA PAULA CANDIDO DOS SANTOS

Avaliação da Punção Aspirativa por Agulha Fina (PAAF) em cavidade oral e região de cabeça e pescoço em diferentes técnicas de coloração

São Paulo

2014 


\title{
Avaliação da Punção Aspirativa por Agulha Fina (PAAF) em cavidade oral e região de cabeça e pescoço em diferentes técnicas de coloração
}

\author{
Versão Corrigida
}

Tese apresentada à Faculdade de Odontologia da Universidade de São Paulo, para obter o título de Doutor, pelo Programa de Pós-Graduação em Odontologia.

Área de Concentração: Diagnóstico Bucal

Orientador: Prof. Dr. Celso Augusto Lemos Jr.

São Paulo 
Autorizo a reprodução e divulgação total ou parcial deste trabalho, por qualquer meio convencional ou eletrônico, para fins de estudo e pesquisa, desde que citada a fonte.

\section{Catalogação da Publicação}

Serviço de Documentação Odontológica

Faculdade de Odontologia da Universidade de São Paulo

Santos, Ana Paula Candido dos.

Avaliação da punção aspirativa por agulha fina (PAAF) em cavidade oral e região de cabeça e pescoço em diferentes técnicas de coloração / Ana Paula Candido dos Santos; orientador Celso Augusto Lemos Júnior. -- São Paulo, 2014.

82p. : fig., tab., graf. ; $30 \mathrm{~cm}$.

Tese (Doutorado) -- Programa de Pós-Graduação em Ciências Odontológicas. Área de Concentração: Diagnóstico Bucal. -- Faculdade de Odontologia da Universidade de São Paulo.

Versão corrigida.

1. Sensibilidade (Odontologia). 2. Neoplasias. 3. Punções. 4. Patologia Bucal. I. Lemos Júnior, Celso Augusto. II. Título 
Santos APC. Avaliação da Punção Aspirativa por Agulha Fina (PAAF) em cavidade oral e região de cabeça e pescoço em diferentes técnicas de coloração. Tese apresentada à Faculdade de Odontologia da Universidade de São Paulo para obtenção do titulo de Doutor em Odontologia.

Aprovado em: $\ldots$

\section{Banca Examinadora}

Prof(a). Dr(a).

Insituição: Julgamento:

Prof(a). Dr(a).

Insituição: Julgamento:

Prof(a). Dr(a).

Insituição: Julgamento:

Prof(a). Dr(a).

Insituição: Julgamento:

Prof(a). Dr(a).

Insituição: Julgamento: 
Dedico este trabalho a todos que estiveram comigo ao longo de todos esses anos, nas alegrias e tristezas. Principalmente aos meus pais, Neyde Pereira Candido dos Santos e Clayton Álvares Baptista dos Santos, ao qual dedico o meu amor incondicional por terem me proporcionado alcançar todos os meus árduos objetivos.

Sem a ajuda de vocês, nada disso seria possível. 


\section{AGRADECIMENTOS}

Agradeço primeiramente aos professores da Disciplina de Estomatologia Clínica Profa. Dra. Andréa Lusvarghi Witzel, Prof. Dr. Dante Antonio Migliari, Prof. Dr. Fábio de Abreu Alves e Prof. Dr. Fernando Ricardo Xavier da Silveira pelo conhecimento transmitido ao longo de todo esse período e pela dedicação a toda disciplina.

Agradeço a Iracema Mascarenhas (Nina) pela ajuda constante e pela dedicação a todos nós e ao departamento.

Agradeço ao CNPq pelo auxílio financeiro.

Agradeço a todos os colegas e amigos do Programa de Pós Graduação em Diagnóstico Bucal em especial a Anna Torrezani, Bianca Fréo, Érica Fernanda Patrício, Gustavo Rodrigues, Vivian Pellegrini, aos já Doutores, Carla Siqueira e Gustavo Rabelo e a hoje, Profa. Dra. Camila de Barros Gallo, por todas as alegrias, bons momentos, força e amizade que dedicaram a mim ao longo de todo esse período o qual estivemos juntos. Tenho certeza de que nossa amizade transpõe os muros desse mundo chamado pós graduação. Sou muito grata por tê-los em minha vida

Agradeço especialmente ao Prof. Dr. Décio dos Santos Pinto Jr. pela dedicação e contribuição ao trabalho.

Ao Prof. Dr. Norberto Nobuo Sugaya que me acolheu desde o começo, norteou o início de toda essa pesquisa e me transmite seu conhecimento todos os dias. Não tenho palavras a te agradecer.

E agradeço, sobretudo, ao meu orientador Prof. Dr. Celso Augusto Lemos Jr. pela paciência, amizade, dedicação, conhecimento transmitido e orientação deste trabalho. Muito obrigada, por tudo, e por todos os momentos de compreensão e dedicação. Serei sempre muito grata por tudo o que fez por mim. 
'Underneath this smile lies everything All my hopes and anger, pride and shame Make myself a pact, not to shut doors on the past Just for today I am free

I will not lose my faith It's an inside job today

I know this one thing

I used to try and kill love, it was the highest sin Breathing insecurity out and in

Searching hope, I'm shown the way to run straight Pursuing the greater way for all human light.

How I choose to feel is how I am.

I will not lose my faith It's an inside job today

Holding on, the light of night On my knees to rise and fix my broken soul

Again.

Let me run into the rain To be a human light again

Let me run into the rain To shine a human light today

Life comes from within your heart and desire' Ed Vedder 


\section{RESUMO}

Santos APC. Avaliação da Punção Aspirativa por Agulha Fina (PAAF) em cavidade oral e região de cabeça e pescoço em diferentes técnicas de coloração [tese]. São Paulo: Universidade de São Paulo, Faculdade de Odontologia; 2014. Versão Corrigida.

O presente estudo teve como objetivo avaliar a Punção Aspirativa por Agulha Fina (PAAF) em diferentes técnicas de coloração, em lesões nodulares de cavidade oral e região de cabeça e pescoço, quanto a sua sensibilidade, especificidade e acurácia, nas colorações de Panótico, Papanicolau e Hematoxilina-Eosina. Foram selecionados 46 pacientes consecutivamente que procuraram a Clínica da Disciplina de Estomatologia Clínica da FOUSP, portadores de lesões nodulares em cavidade oral e região de cabeça e pescoço. Como critérios de inclusão foram selecionados pacientes de ambos os sexos, todas as etnias, acima dos 5 anos de idade, sem restrição de comorbidades e que foram realizadas PAAF com confirmação diagnóstica pela biópsia. Como critérios de exclusão da pesquisa estão os pacientes abaixo dos 5 anos de idade e pacientes que foram somente submetidos a PAAF sem confirmação diagnóstica pela biópsia. O material obtido pela PAAF foi enviado em 6 lâminas diferentes, corados pelo método de Panótico, Papanicolau e HematoxilinaEosina a um mesmo patologista apenas com o diagnóstico clínico. Após a emissão do laudo da PAAF, o laudo do anátomo patológico era emitido, servindo como padrão ouro. Após os cálculos, o resultado da sensibilidade, especificidade e acurácia para o método de coloração com o Panótico foram de 28,6\%, 76\%, 15,4 , respectivamente, para o método de coloração com o Papanicolau foram de $71,4 \%, 76,7 \%, 23,3 \%$, respectivamente e para o método de coloração com a Hematoxilina-Eosina foram de $82,1 \%, 23,3 \%, 28,6 \%$, respectivamente. Houve diferença estatisticamente significativa na proporção de sensibilidade, especificidade e acurácia entre as diferentes técnicas de coloração (X2 13,27, $p=0,01)$. Podemos concluir que, na metodologia do presente estudo, as colorações de Hematoxilina-Eosina e Papanicolau demonstraram a mesma sensibilidade, para diagnosticar neoplasias malignas. A coloração de Hematoxilina-Eosina demonstrou uma melhor especificidade para diagnosticar 
neoplasias benignas, quando comparadas com a colorações de Papanicolau e Panótico. A coloração de Hematoxilina-Eosina demonstrou uma melhor acurácia, para dar diagnóstico definitivo, seguida das colorações de Papanicolau e Panótico.

Palavras Chave: PAAF, Sensibilidade, Especificidade, Acurácia, Técnicas de coloração. 


\section{ABSTRACT}

Santos APC. Evaluation of Fine Needle Aspiration Biopsy (FNAB) in oral cavity and head and neck region with different techniques stains [thesis]. São Paulo: Universidade de São Paulo, Faculdade de Odontologia; 2014. Versão Corrigida.

The present study aimed to evaluate the Fine Needle Aspiration Biopsy in different staining techniques in nodular lesions of the oral cavity and head and neck region, as their sensitivity, specificity and accuracy, staining with Panoptic, Papanicolaou and Hematoxylin-Eosin. 46 patients who sought the Clinic of the Discipline of Clinical Stomatology at FOUSP were selected consecutively, with nodular lesions in the oral cavity and head and neck region. Inclusion criteria were patients of both sexes, all ethnicities, above 5 years-old, with no restriction of comorbidities and FNAB performed with confirmation by biopsy. Exclusion criteria were patients under 5 years-old and patients who only underwent FNAB without confirmation by biopsy. The material obtained by FNAB was sent on 6 different slides, stained by the method of Panoptic, Papanicolaou and Hematoxylin-Eosin, to the same pathologist only with the clinical diagnosis. After the final report of FNAB, the biopsy report was issued, serving as gold standard. After the calculations, the results of sensitivity, specificity and accuracy for Panoptic staining were $28.6 \%, 76 \%$ and $15.4 \%$, respectively. The result of sensitivity, specificity and accuracy for Papanicolaou staining were $71,4 \%, 76.7 \%$ and $23.3 \%$, respectively. The result of sensitivity, specificity and accuracy for Hematoxylin-Eosin staining were $82.1 \%, 23.3 \%, 28.6 \%$, respectively. There was a statistically significant difference in the proportion of sensitivity, specificity and accuracy between the different staining techniques (X2 13.27, $p=0.01$ ). We can conclude, in the methodology of this study that, Hematoxylin-Eosin and Papanicolaou stains showed the same sensitivity of diagnosing malignant neoplasms. The Hematoxylin-Eosin stain showed a better specificity for diagnosing benign neoplasms, compared with Papanicolaou and Panoptic stains. Hematoxylin-eosin stain showed better accuracy, to give definitive diagnosis, followed by Papanicolaou and Panoptic stains.

Keywords: FNAB, Sensitivity, Specificity, Accuracy, Staining techniques 


\section{LISTA DE ABREVIATURAS}

${ }^{\circ} \mathrm{GL} \quad{ }^{\circ}$ Gay Lussac

FN Falso-negativo

FNAB Fine Needle Aspiration Biopsy

FP Falso-positivo

G Gauge

LPNN Lesão Proliferativa Não Neoplásica

CR Cistos Reacionais

$\mathrm{ml} \quad$ mililitro

LB Lesões Benignas

NM Neoplasia Maligna

PAAF Punção Aspirativa por Agulha Fina

PI Processo Inflamatório

PCR Reação em Cadeia da Polimerase 


\section{LISTAS DE ILUSTRAÇÕES}

Figura 5.1 - Aspecto intra-oral lesão nodular em mucosa jugal, com hipótese diagnóstica de Neoplasia Glandular Benigna

Figura 5.2 - Aspecto intra-oral de lesão nodular em região de maxila anterior, com hipótese diagnóstica de Lesão Central de Células Gigantes ( $A$ e B)

Figura 5.3 - Radiografia Panorâmica demostrando lesão óssea em Maxila e Mandíbula na região anterior

Figura 5.4 - Aspecto intra-oral de lesão nodular em maxila e radiografia oclusal demostrando lesão óssea em região de palato duro, com hipótese diagnóstica de cisto do ducto do nasopalatino

Figura 5.5 - Aspecto extra-oral de lesão nodular em região de mandíbula direita, com hipótese diagnóstica de neoplasia maligna

Figura 5.6 - Radiografia Panorâmica demonstrando lesão óssea destrutiva em corpo e ramo da mandíbula

Fotomicrografia 5.1 - Presença de células plasmocitóides no esfregaço, em menor e maior aumento, com laudo sugestivo de adenoma pleomórfico, em coloração de Panótico

Fotomicrografia 5.2 - Presença de células plasmocitóides no esfregaço, em menor e maior aumento, com laudo sugestivo de adenoma pleomórfico, em coloração de Papanicolau 
Fotomicrografia 5.3 - Presença de células plasmocitóides no esfregaço, em menor e maior aumento, com laudo sugestivo de adenoma pleomórfico, em coloração de HematoxilinaEosina

Fotomicrografia 5.4 - Corte histológico, com laudo definitivo de Adenoma Pleomórfico, em coloração de Hematoxilina-Eosina

Fotomicrografia 5.5 - Presença de células gigantes no esfregaço, em menor e maior aumento, com laudo sugestivo de Lesão Central de Células Gigantes, em coloração de Panótico

Fotomicrografia 5.6 - Presença de células gigantes no esfregaço, em menor e maior aumento, com laudo sugestivo de Lesão Central de Células Gigantes, em coloração de Papanicolau

Fotomicrografia 5.7 - Presença de células gigantes no esfregaço, em menor e maior aumento, com laudo sugestivo de Lesão Central de Células Gigantes, em coloração de Hematoxilina-Eosina

Fotomicrografia 5.8 - Presença de coagulo amorfo nos esfregaços das lâminas coradas com Panótico e Papanicolau, com laudo sugestivo de conteúdo cístico

Fotomicrografia 5.9 - Presença de coagulo amorfo nos esfregaços de lâmina corada com Hematoxilina-Eosina, com laudo sugestivo de conteúdo cístico

Fotomicrografia 5.10 - Presença de células multinucleadas atípicas no esfregaço, em menor e maior aumento, com laudo sugestivo de neoplasia mesenquimal maligna, em coloração de Panótico 
Fotomicrografia 5.11 - Presença de células multinucleadas atípicas no esfregaço, em menor e maior aumento, com laudo sugestivo de neoplasia mesenquimal maligna, em coloração de Papanicolau

Fotomicrografia 5.12 - Presença de células multinucleadas atípicas no esfregaço, em menor e maior aumento, com laudo sugestivo de neoplasia mesenquimal maligna, em coloração de Hematoxilina-Eosina 


\section{LISTA DE GRÁFICOS}

Gráfico 5.1 - Distribuição dos 46 pacientes por gênero

Gráfico 5.2 - Distribuição dos 46 pacientes por etnia

Gráfico 5.3 - Distribuição do número casos por faixa etária 46

Gráfico 5.4 - Tipos de neoplasias presentes nos 46 pacientes estudados

Gráfico 5.5 - Número de casos inconclusivos presentes nas três colorações.

Gráfico 5.6 - Número de casos inconclusivos presentes nas duas colorações .53 


\section{LISTA DE TABELAS}

Tabela 5.1 - Total de lesões diagnosticadas pela PAAF pelo método de Panótico ....50

Tabela 5.2 - Total de lesões diagnosticadas pela PAAF pelo método de Papanicolau 50

Tabela 5.3 - Total de lesões diagnosticadas pela PAAF pelo método de Hematoxilina-Eosina

Tabela 5.4 - Cálculo de sensibilidade e especificidade no método de coloração por Panótico

Tabela 5.5 - Cálculo de sensibilidade e especificidade no método de coloração por Papanicolau

Tabela 5.6 - Cálculo de sensibilidade e especificidade no método de coloração por Hematoxilina-Eosina

Tabela 5.7 - Comparação das três técnicas de coloração de acordo com sua sensibilidade, especificidade e acurácia

Tabela 5.8 - Total de lesões diagnosticadas pela PAAF pelo método de Papanicolau

Tabela 5.9 - Total de lesões diagnosticadas pela PAAF pelo método de Hematoxilina-Eosina

Tabela 5.10 - Cálculo de sensibilidade e especificidade no método de coloração por Papanicolau

Tabela 5.11 - Cálculo de sensibilidade e especificidade no método de coloração por Hematoxilina-Eosina. 
Tabela 5.12 - Comparação das duas técnicas de coloração de acordo com sua sensibilidade, especificidade e acurácia ...........................................56

Tabela 5.13 - Descrição de local da lesão e resultados do Panótico, HE, Papanicolau e Anátomo Patológico 63 


\section{SUMÁRIO}

1 INTRODUÇÃO

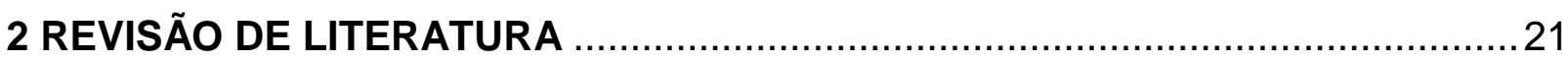

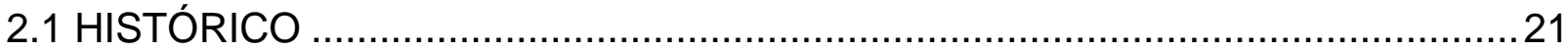

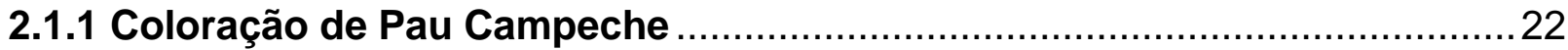

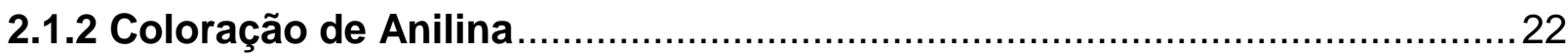

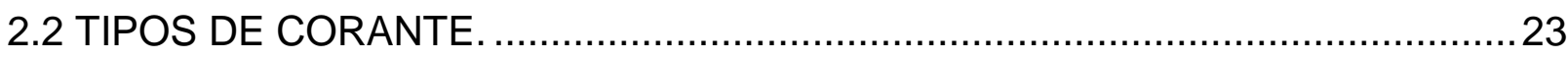

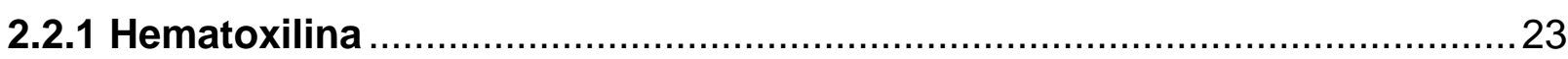

2.2.2 Eosina

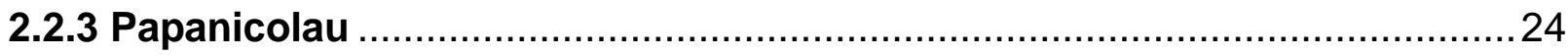

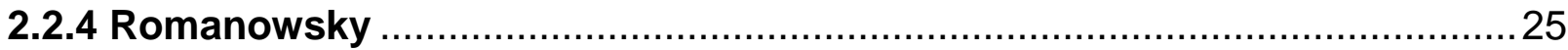

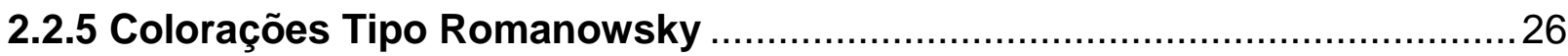

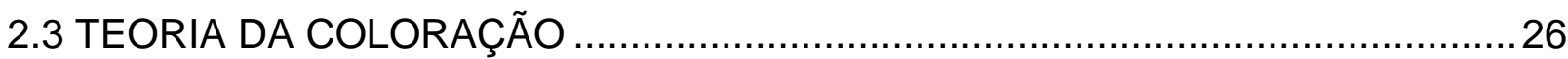

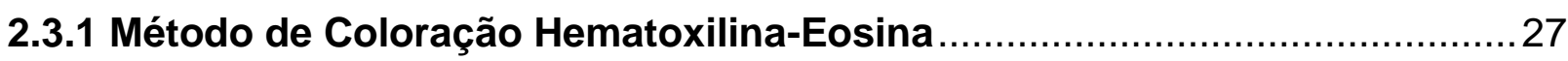

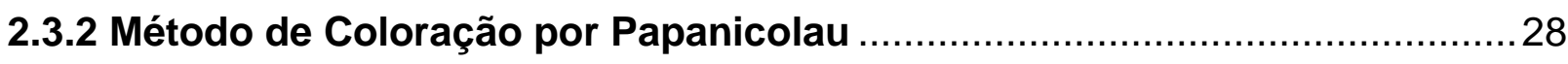

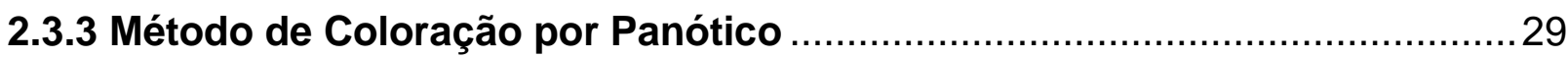

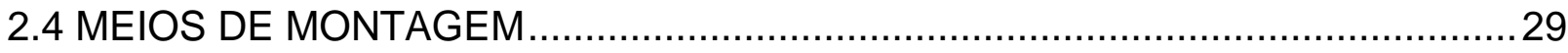

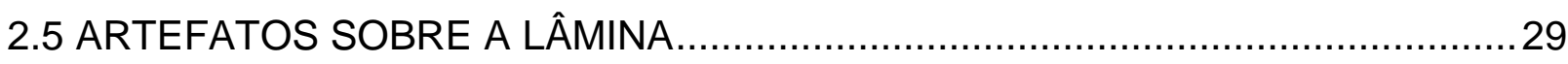

2.6 DIAGNÓSTICO CITOPATOLÓGICO POR PUNÇÃO ASPIRATIVA POR

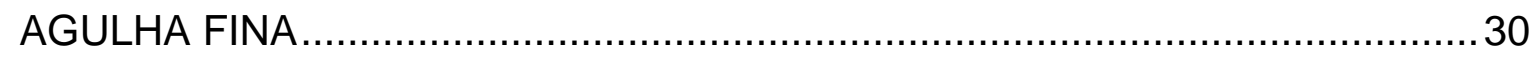

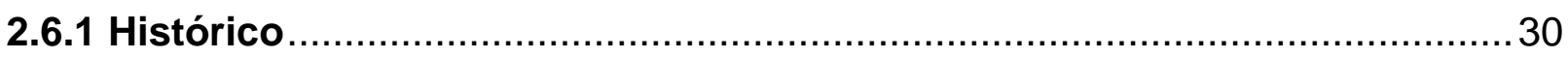

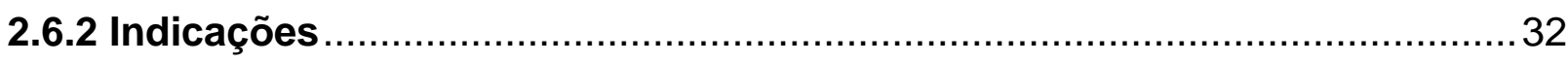

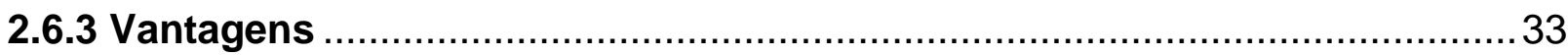

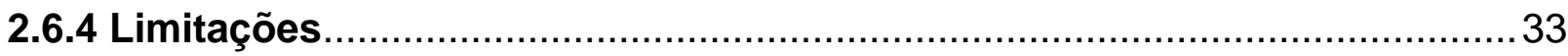

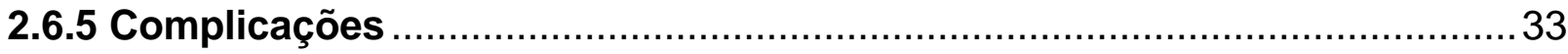

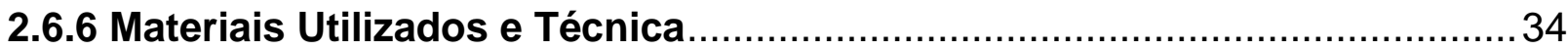

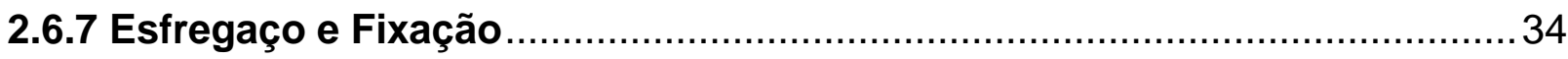

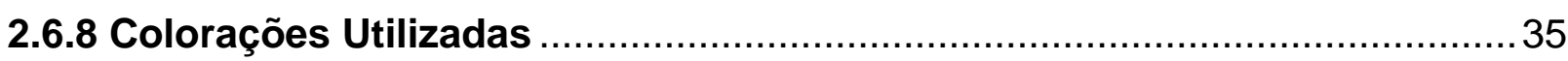

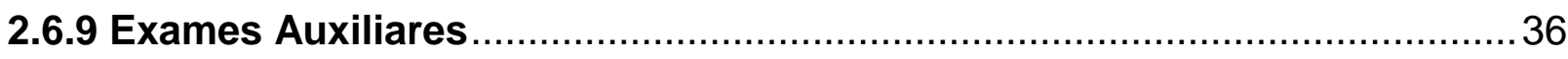

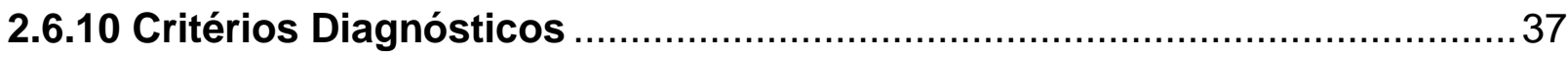

2.6.11 Sensibilidade, Especificidade e Acurácia .............................................. 
2.6.12 Região de Cabeça e Pescoço, Glândulas Salivares e Cavidade Oral ........38

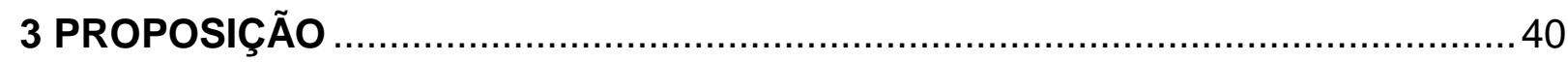

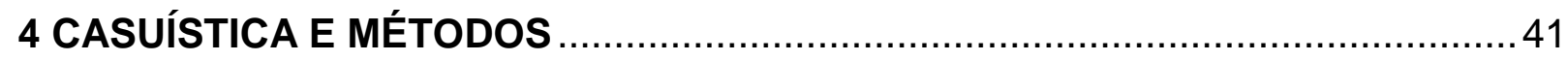

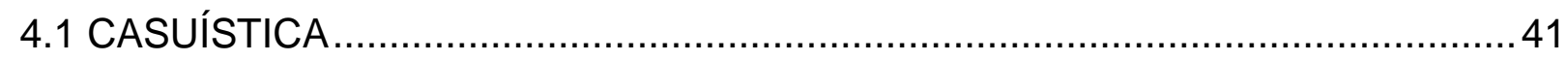

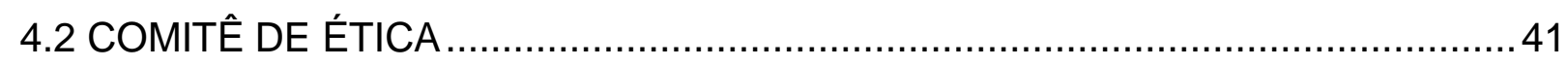

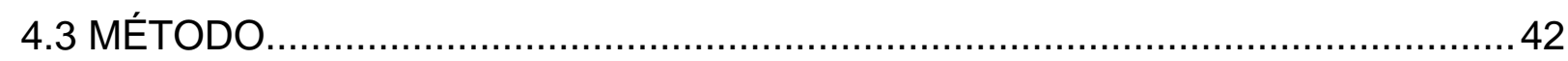

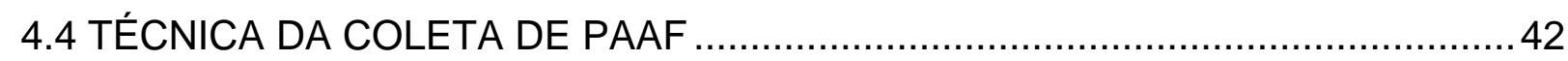

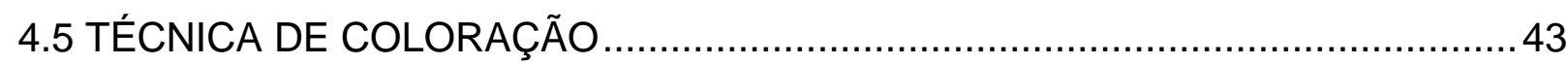

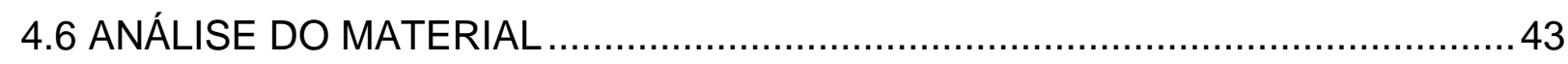

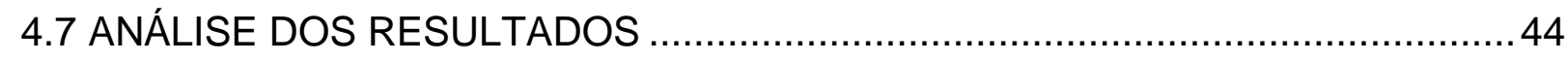

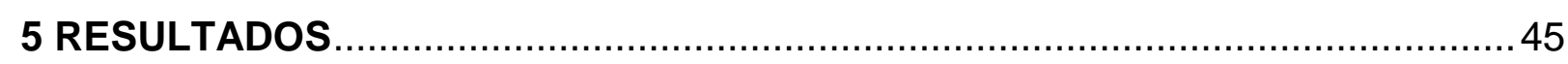

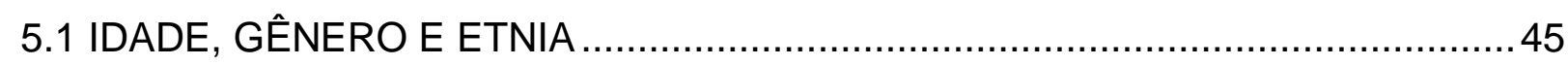

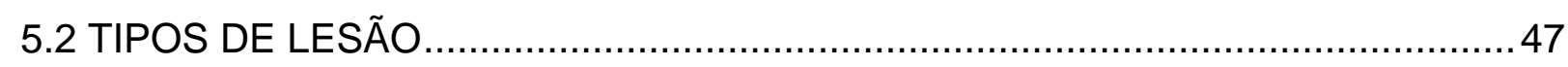

5.3 CÁLCULO DA SENSIBILIDADE, ESPECIFICIDADE E ACURÁCIA ....................48

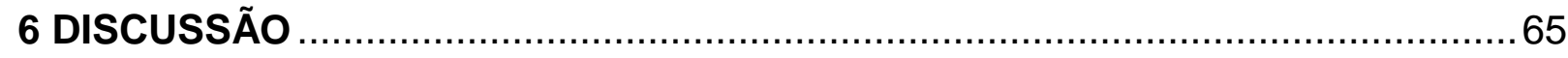

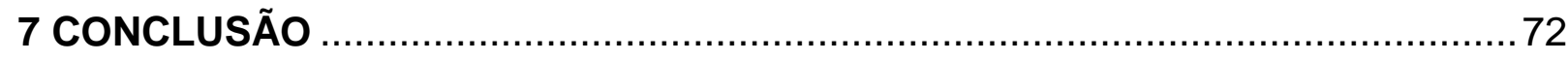

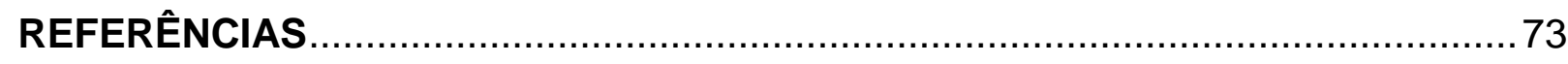

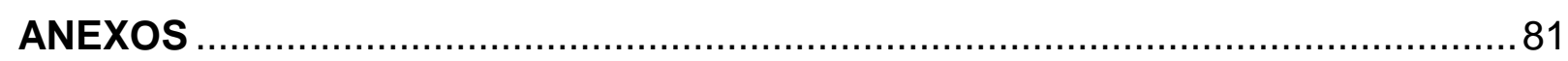




\section{INTRODUÇÃO}

A coloração histológica é uma técnica que facilita o estudo microscópico de um tecido por meio da diferenciação de cor do mesmo (Tolosa, 2003). As colorações mais utilizadas na Punção Aspirativa por Agulha Fina (PAAF) são o as colorações tipo Romanowsky (Panótico - coloração de rápida visualização), o Papanicolau e a Hematoxilina-Eosina, sendo essa última a menos utilizada nessa técnica (Kline, 1988; Koss, 1979b; Koss, 1992; Ansari; Derias, 1997). Na histologia há uma grande variedade de corantes. Os corantes ácidos coram formações básicas, os corantes básicos coram formações ácidas, os corantes neutros se misturam e coram as funções químicas opostas e os corantes metacromáticos, são os que em um mesmo corante, conferem cores diferentes ao tecido (Bancroft, 1996; Tolosa, 2003).

A Hematoxilina é natural e tem pouca afinidade ao tecido quando usada isoladamente. Ela somente vira corante quando oxidada e seu principio ativo depois dela oxidada é a hemanteína (Bancroft, 1996; Tolosa, 2003). A Eosina é um corante ácido, da família dos xantenos, que cora todos os outros tecidos que a hematoxilina não cora, em uma variedade de rosa intenso, laranja ou vermelho (Bancroft, 1996; Tolosa, 2003). A coloração de Papanicolau é policromática e mostra variações de morfologia celular, seus graus na matriz celular e atividade metabólica (Keebler; Somrak, 1993). As colorações do tipo Romanowsky são colorações policromáticas que se baseiam no principio de Romanowsky. Essas colorações são as de Wright, a coloração de Giemsa, a coloração de May-Grüwald-Giemsa e o Diff-Quick ${ }^{\circledR}$ (coloração de Wright-Giemsa ou Panótico rápido) (Ramzy, 1990; Keebler; Somrak, 1993).

As colorações mais utilizadas em PAAF na cavidade oral, são as mesmas de outras regiões, as colorações tipo Romanowsky para lâminas secas ao ar e as colorações de Papanicolau e Hematoxilina-Eosina, para as lâminas fixadas em álcool (Castelli et al., 1993; Saleh et al., 2008; Fitzhugh et al., 2009; Santos et al., 2011).

O objetivo do presente estudo é avaliar a sensibilidade, especificidade e acurácia da PAAF em diferentes técnicas de coloração para lesões nodulares de cavidade oral e região de cabeça e pescoço. 


\section{REVISÃO DE LITERATURA}

A coloração histológica é uma técnica que facilita o estudo microscópico de um tecido por meio da diferenciação de cor do mesmo (Tolosa, 2003). As colorações mais utilizadas na Punção Aspirativa por Agulha Fina (PAAF) são as colorações tipo Romanowsky (Panótico - coloração de rápida visualização), o Papanicolau e a Hematoxilina-Eosina, sendo essa última a menos utilizada nessa técnica (Kline, 1988; Koss, 1979; Koss, 1992; Ansari; Derias ,1997).

\subsection{HISTÓRICO}

Historicamente, Robert Hooke, em 1665, pode ter sido o primeiro a visualizar a aparência de um objeto corado microscopicamente por ter visto um cabelo após ser tingido em seu microscópio. Um pouco mais tarde Leeuwenhoek, em 1719, aplicou açafrão para ajudar na elucidação da estrutura microscópica do tecido muscular, sendo o primeiro a corar um tecido biológico para estudo do mesmo (Clark; Kasten, 1983).

Risch, em 1724 injetou cinábrio (sulfeto de mercúrio) nos vasos sanguíneos humanos em uma mistura juntamente com sebo e cera para seu estudo microscópico e em 1774, Trembley alimentou espécies de Hidra com uma grande variedade de organismos coloridos. Os dois se aventuraram na coloração vital, mas não contribuíram para a técnica histológica (Clark; Kasten, 1983).

Sir John Hill foi o primeiro a usar carmim como coloração histológica e possuí várias contribuições na área de botânica, mas foi Joseph Von Gerlach, que por muitos anos foi considerado o iniciador da técnica de coloração moderna, que contribuiu significativamente para a anatomia e a técnica microscópica com o uso de carmim (Clark; Kasten, 1983).

Joseph Von Gerlach corou por acidente células e fibras nervosas, deixando de um dia para o outro um cerebelo embebido em bicromato de potássio em uma 
solução bem diluída de carmim podendo então visualizar suas nuances (Clark; Kasten, 1983).

\subsubsection{Coloração de Pau Campeche}

O extrato de Pau Campeche foi a primeira coloração da era modera empregada na histologia. Desse extrato, sai a Hematoxilina em sua forma purificada (Clark; Kasten, 1983).

A hematoxilina não é a coloração propriamente dita, e sim o fruto de sua oxidação, a hemanteína, que cora os tecidos (Clark; Kasten, 1983).

O primeiro a usar Hematoxilina foi Waldeyer, um biólogo, em 1863, porém sua tentativa foi falha pois não usou o produto oxidado e acabou abandonando seu uso (Clark; Kasten, 1983).

Após isso, Böhmer notou que na indústria o alumínio era muito utilizado como mordente e que este, juntamente com a Hematoxilina, corava mais fortemente do que sem ele. Notou também que preparações tratadas em ácido crômico, bicromato de potássio, sulfato de cobre e outros sais metálicos, os tecidos coloravam em azul (Clark; Kasten, 1983).

Mayer, em 1891, apontou que o amadurecimento da Hematoxilina alúmen nada mais é que o seu produto final, a hemanteína (Clark; Kasten, 1983).

\subsubsection{Coloração de Anilina}

Foi entre os anos de 1875 e 1880 quando as colorações de anilina começaram a ser introduzidas na histologia nas combinações de duplas coloração (Clark; Kasten, 1983).

Fischer, em 1876, introduziu o uso da Eosina para corar vários tecidos (Clark; Kasten, 1983). 


\subsection{TIPOS DE CORANTE}

$\mathrm{Na}$ histologia há uma grande variedade de corantes. Os corantes ácidos coram formações básicas, os corantes básicos coram formações ácidas, os corantes neutros se misturam, corando as funções químicas opostas e os corantes metacromáticos são os que em um mesmo corante, conferem cores diferentes ao tecido (Bancroft, 1996; Tolosa, 2003).

\subsubsection{Hematoxilina}

A Hematoxilina é natural e tem pouca afinidade ao tecido quando usada isoladamente. A combinação com sais de Alumínio, Ferro, Cobre e Tungstênio conferem uma grande afinidade da hematoxilina com o tecido nuclear. O princípio ativo depois dela oxidada é a hemanteína (Bancroft, 1996; Tolosa, 2003).

A oxidação da Hematoxilina leva a sua maturação e pode acontecer de duas maneiras (Bancroft, 1996; Tolosa, 2003):

- Natural: onde é exposta ao ar e a luz, o que leva de 3 a 4 meses e a solução resultante parece corar por mais tempo e durar mais

- Química: por uso de agentes oxidantes como óxido de mercúrio e iodato de sódio, no qual o processo é quase instantâneo, sendo prontas para o uso logo após a preparação, com um tempo de vida útil menor, pois o processo continua pela luz e pelo ar

A classificação das Hematoxilinas são (Bancroft, 1996; Tolosa, 2003):

- Hematoxilina Alúmen: Ehrlich, Harris, Mayer;

- Hematoxilina Ferrosa de Weigert;

- Hematoxilina-Ácido Fosfotúngstico;

- Hematoxilina de Heidenhain. 
As Hematoxilinas Alúmen são as mais utilizadas, conferindo cor vermelha aos núcleos e quando lavada com substância alcalina fraca, os núcleos coram de cor azul ou negros (Bancroft, 1996; Tolosa, 2003).

\subsubsection{Eosina}

A Eosina é um corante ácido, da família dos xantenos, que cora todos os outros tecidos que a hematoxilina não cora, em uma variedade de rosa intenso, laranja ou vermelho. Combinada com a Hematoxilina Alúmen, demostra a arquitetura do tecido, distinguindo o citoplasma de diferentes tipos celulares e de tecidos de conexão, fibras e matrizes em diferentes nuances de vermelho e rosa (Bancroft, 1996; Tolosa, 2003).

Os tipos de Eosina são (Bancroft, 1996; Tolosa, 2003):

- Eosina $Y$ - de cor amarelada e mais usada

- Eosina Etílica (S)

- Eosina B - de coloração azulada

\subsubsection{Papanicolau}

George N. Papanicolaou foi um médico grego que, em 1941, descreveu dois artigos sobre a citologia de células vaginais, no estudo de carcinoma cervical. Para a melhor visualização das células nesse exame, ele criou a coloração de Papanicolau que é utilizada para exames citológicos até os dias atuais (Gray, 1995).

Essa coloração foi descrita primeiramente em 1942, e foi modificada pelo próprio Papanicolaou nos anos de 1954 e 1960 (Koss, 1979b).

A coloração de Papanicolau é policromática e mostra variações de morfologia celular e seus graus na matriz celular e atividade metabólica (Keebler; Somrak, 1993). 
No teste citológico acontece uma sobreposição celular e há células que permanecem intactas, demonstrando uma imagem em 3D, por esse motivo, na visualização microscópica e no momento da coloração ocorre uma certa transparência celular, quando coradas pela técnica de Papanicolau (Koss, 1979b; Keebler; Somrak, 1993).

A solução de Papanicolau possui um alto teor alcoólico e isso facilita um contraste na coloração, permitindo a clara visualização pelas áreas onde as células estão sobrepostas, onde há muco e restos celulares (Koss, 1979b; Keebler; Somrak, 1993, Jörundsson et al., 1999).

O fixador utilizado para a coloração é o álcool. Após realizado o processo, ocorre uma coloração nuclear mostrando padrões únicos de cromatina, encontrados em células normais e não normais (Koss, 1979b; Keebler; Somrak, 1993, Jörundsson et al. 1999).

\subsubsection{Romanowsky}

A técnica foi descrita em 1841 por Dmitry Leonidovich Romanowsky, um médico russo, quando lançou sua monografia em parasitologia e no tratamento de malária. Romanowsky se baseou na escolha das colorações baseadas no trabalho de Cheslav Ivanovich Chenzinsky, que usou uma mistura de Azul de Metileno e eosina (Berzukov, 2010)

Romanowsky percebeu, então, que havia o aparecimento de uma terceira coloração na modificação de sua técnica, que depois ficou conhecida como o Azure $B$, um produto de oxidação do Azul de Metileno. Esse produto junto com a Eosina cora a cromatina em roxo, provocando o Efeito Romanowsky, que nada mais é que a visualização de uma coloração policromática, sendo o roxo a coloração mais importante (Berzukov, 2010; Jörundsson et al., 1999).

A coloração de Romanowsky possui Azure B, Eosina Y e homólogos de Azul de Metileno. Sua categorização e reconhecimento das células normais e patológicas sanguíneas e de medula óssea é bem estabelecida (Horobin; Walter, 1987; Jörundsson et al., 1999). 


\subsubsection{Colorações tipo Romanowsky}

Vários tipos de coloração são considerados tipo Romanowsky, como a coloração de Wright, a coloração de Giemsa, a coloração de May-Grünwald-Giemsa e o Diff-Quick ${ }^{\circledR}$ (coloração de Wright-Giemsa ou Panótico rápido) (Ramzy, 1990; Keebler; Somrak, 1993).

O Panótico, é um corante de forma rápida e se baseia na coloração hematológica estabelecida por Romanowsky. É uma coloração do tipo policromática contendo um corante ácido (xanteno), um corante básico (tiazina) e um fixador (Triarilmetano). As lâminas devem ser secas ao ar e depois coradas de acordo com a técnica descrita pelo fabricante (Keebler; Somrak, 1993).

\subsection{TEORIA DA COLORAÇÃO}

A coloração pode se dar de três maneiras (Bancroft, 1996; Tolosa, 2003):

- Negativa - as estruturas são radiadas pelo corante, mas não penetradas por ele

- Coloração Vital - o corante é introduzido nas células vivas e são fagocitados por elas, em um organismo vivo

- Coloração Supravital - o tecido é corado após ser removido do organismo

A captação da coloração se dá pela afinidade entre o corante e o tecido ou pelo reagente e o tecido (Bancroft, 1996; Tolosa, 2003).

A afinidade por corante se dá quando o componente é intensamente corado. Pode ser entendido pelas forças atrativas que ligam o tecido ao corante e a tendência de um corante se transferir para o corte. Essa afinidade depende de todo e qualquer fator auxiliando ou dificultando esse processo, como por exemplo, a interação entre solvente-solvente, coloração-solvente, coloração-coloração e a interação entre coloração-tecido (Bancroft, 1996; Tolosa, 2003). 
Os métodos de coloração podem ser (Tolosa, 2003):

- Simples - feitos somente por um corante

- Duplos - feito por duas colorações

- Múltiplos - feito por duas ou mais colorações

Após as lâminas serem coradas, podemos classificar os corantes de duas maneiras (Tolosa, 2003):

- Corante diferencial - corante específico para uma determinada estrutura

- Contra - corante - secundário, cora o que o corante diferencial não corou

\subsubsection{Método de Coloração Hematoxilina-Eosina}

Há dois métodos de coloração por Hematoxilina-Eosina (Bancroft, 1996; Tolosa, 2003):

- Progressivo - a Hematoxilina é usada com excesso de sais de alumínio ou ácido, aumentando a seletividade cromática nuclear. Após a lavagem permite coloração secundária

- Regressivo - os tecidos são corados em excesso por solução de Hematoxilina neutra. $O$ excesso é então removido com solução álcoolácido. Os cortes então são neutralizados com solução fraca de hidróxido de amônia em água ou carbonato de lítio. O tecido fica com o citoplasma incolor e o núcleo com metacromasia

A Eosina cora então as outras estruturas, demostrando também inclusões e alterações citoplasmáticas (Bancroft, 1996; Tolosa, 2003). 


\subsubsection{Método de Coloração por Papanicolau}

Os corantes utilizados na coloração de Papanicolau são (Koss, 1979b; Keebler; Somrak, 1993):

- Hematoxilina de Harris

- Orange G

- EA36 ou EA65 - uma mistura de verde luz amarelado, Eosina Y, escarlate de Biebrich e Pardo Bismark

Há dois métodos de coloração por Papanicolau (Koss, 1979b):

- Técnica I - usa Hematoxilina de Harris regressivamente. As células são super coradas e o excesso de Hematoxilina removido por uma extração diferencial em $\mathrm{HCl}$

- Técnica II - uso progressivo de Hematoxilina sem a extração diferencial em HCl. Diminui, portanto, o tempo de coloração prevenindo o excesso de coloração do citoplasma

A Hematoxilina cora os núcleos e o Orange G, o E36 ou E65 coram as estruturas básicas do citoplasma. O resultado disso é o núcleo corando em um tom de azul, o citoplasma de uma cor cinza ou verde e as células queratinizadas em um tom de laranja e rosa (Koss, 1979b; Keebler; Somrak, 1993; Tolosa, 2003).

Para tecidos não ginecológicos, o método mais utilizado é o progressivo, pois não há aderência dos tecidos nas lâminas (Keebler; Somrak, 1993). 


\subsubsection{Método de Coloração por Panótico}

Utilizam-se três soluções para a coloração rápida do panótico, o xanteno, a tiazina e o triarilmetano, os quais devem ser utilizados de acordo com a técnica preconizada pelo fabricante (Keebler; Somrak, 1993).

Lâminas com coloração muito avermelhadas indicam uma acidez excessiva e lâminas muito azuladas indicam um alcalinidade excessiva (Keebler; Somrak, 1993).

\subsection{MEIOS DE MONTAGEM}

Para que a lâmina seja visualizada no microscópio, se emprega uma substância para ficar em cima do corte corado e uma lamínula para que esse corte seja conservado (Tolosa, 2003).

Há dois grupos de substâncias (Tolosa, 2003):

- Miscíveis em água - aquosas

- Não miscíveis em água - resinosas

\subsection{ARTEFATOS SOBRE A LÂMINA}

Alguns artefatos atrapalham na visualização dos cortes histológicos (Tolosa, 2003):

- Presença de cristais de alúmen - os mesmos não foram bem misturados na confecção do corante

- Coloração desigual - proveniente de muita agitação das lâminas no momento de sua coloração 
- Desidratação incompleta do corte - provocam um aspecto cinzento e granuloso nos cortes histológicos, com presença de bolhas

- Não secar a lâmina para a aplicação da lamínula - presença de um pontilhado que se assemelha a depósito de pigmentos, núcleos negros e brilhantes

- Meio de montagem em excesso - aparência nebulosa do tecido quando em maior aumento

\subsection{DIAGNÓSTICO CITOPATOLÓGICO POR PUNÇÃO ASPIRATIVA POR AGULHA FINA}

A Punção Aspirativa por Agulha Fina (PAAF) é uma modalidade de exame citológico, que visa o estudo das células colhidas por meio de uma agulha fina e um sistema a vácuo, acoplados a uma seringa (Kline, 1988). Com esse exame, se reconhece padrões morfológicos celulares e com isso se obtém o diagnóstico de uma determinada lesão (Kline, 1988; Ramzy, 1990; Koss, 1992; Amedee; Dhurandhar, 2001).

\subsubsection{Histórico}

Os primeiros relatos de aspiração por agulha para fins diagnósticos data de 1847, por Kun (Ansari; Derias, 1997; Costas et al., 2000; Amedee; Dhurandhar, 2001; Santos et al., 2011). No século XIX, alguns poucos relatos de casos foram reportados (Ansari ; Derias, 1997).

Em 1883, Leydon, usou a aspiração para obter microorganismos pulmonares, provenientes de pneumonia. Em 1886, Menitrier, relatou sua aspiração de células de carcinoma pulmonar (Ansari; Derias, 1997).

Em 1904, Griegg e Grey, fizeram diagnóstico de tripanossomíase em linfonodos de pacientes com a doença do sono (Ansari; Derias, 1997). 
Em 1927, Dudgeon e Patrick fizeram na Inglaterra, aspirações de tumores para diagnóstico rápido (Ansari; Derias, 1997).

Foi nos anos 30, que Martin e Ellis fizeram uma série de aspirações em vários órgãos no Memorian Hospital em Nova lorque. O crédito vai ao patologista, Fred W. Stewart, que avaliou as 2.500 lâminas e considerou alguns pontos para se obter bons resultados na técnica e que são utilizados até hoje como: experiência na coleta e preparação das amostras, correlação da informação clinica com a interpretação do material coletado, interpretação correta depende de padrões morfológicos celulares e a comparação das lâminas de material aspirado com a histologia convencional para avaliar sua acurácia (Kline, 1988; Ansari; Derias, 1997; Zbären et al., 2001; Santos et al., 2011).

A técnica acabou sendo abandonada pelo medo que no momento da coleta do material, houvesse a dispersão das células pelo organismo, causando metástases a distância (Kline, 1988; Ansari; Derias, 1997; Zbären et al., 2001; Santos et al., 2011).

Nos anos 50, a técnica foi retomada por Söderström e Franzén na Suécia e por Lopes-Cardozo na Holanda. Nesse momento, o uso de agulha fina começou a ser mais utilizado (Kline, 1988; Ansari; Derias, 1997; Zbären et al., 2001; Santos et al., 2011).

Zajicek foi o primeiro patologista a acolher a PAAF aplicando rigor científico para definir critérios de diagnóstico precisos em uma variedade de condições. Enfatizou em seus trabalhos a simplicidade da técnica, sua segurança, a rapidez e acurácia diagnóstica, aliados ao histórico clinico, histológico e de follow-up (Kline, 1988; Ansari; Derias, 1997; Zbären et al., 2001; Santos et al., 2011).

Nos anos 70, após a experiência sueca, houve o ressurgimento da técnica por todo mundo, sendo hoje em dia, uma ferramenta diagnóstica bastante utilizada para diagnosticar tecidos neoplásicos benignos e malignos e não neoplásicos de tireóide, região de cabeça e pescoço, mamas e lugares de difíceis acessos para a biópsia convencional (Kline, 1988; Ansari; Derias, 1997; Amedee; Dhurandhar, 2001; Zbären et al., 2001; Santos et al., 2011). 


\subsubsection{Indicações}

As indicações da PAAF são (Kline, 1988; Ramzy, 1990; Wakely Jr.; Kneisl, 2000; Amedee; Dhurandhar, 2001; Florentine et al., 2006):

- Lesões palpáveis: região de cabeça e pescoço. Os locais mais utilizados são a tireóide, glândulas salivares maiores e linfonodos dessa região.

- Lesões profundas: região de tórax e região abdominal. Os locais mais utilizados são mama, pulmões e algumas regiões do abdômen. Nessas lesões mais profundas, a PAAF é guiada pelo exame imaginológico de ultrassom.

Há outras indicações da PAAF. Fergunson, em 1937, acreditava que a PAAF tinha a única função de diferenciar tecidos neoplásicos de não neoplásicos (Kline, 1988). Nos dias atuais, a PAAF é utilizada para diferenciar tecidos neoplásicos de não neoplásicos, mas também processos inflamatórios, processos infecciosos e lesões reativas. Seu uso se estende a coleta de materiais para cultura microbiológicas em lesões infecciosas (Amedee; Dhurandhar, 2001; Fitzhugh et al., 2009; Bagga et al., 2010).

\subsubsection{Vantagens}

As vantagens da PAAF podem ser (Kline, 1988; Ansari; Derias, 1997; Fulciniti et al., 1997; Costas et al., 2000; Wright et al., 2008; Santos et al., 2011):

- Procedimento relativamente indolor

- Rápido resultado, garantindo diminuição entre o diagnóstico da lesão e tratamento

- Baixo custo, pois os produtos utilizados são relativamente baratos

- Pode ser realizada em consultório, sem preparação dos pacientes 
- A experiência na técnica, na coleta e na interpretação dos dados, produz acurácia semelhante a técnica histológica

- Pode ser utilizados em pacientes com comorbidades e em crianças

\subsubsection{Limitações}

Podemos listar algumas limitações da PAAF (Kline, 1988; Ansari; Derias, 1997; Fulciniti et al., 1997; Santos et al., 2011):

- Inexperiência da Coleta - pode causar amostras insuficientes ou inapropriadas para análise

- Falta de arquitetura tecidual presente na histologia - patologista deve ser bem treinado em reconhecer padrões morfológicos celulares

\subsubsection{Complicações}

As complicações mais frequentes da PAAF são (Ansari; Derias, 1997; Fulciniti et al., 1997; Mighell; High, 1998, Tyagi; Dey, 2014):

- De ordem local: hematoma, infecção, edema e hemorragia

- Metástases a distância ou no trajeto da agulha: geralmente ocorre quando se faz várias coletas de uma devida lesão. A coleta feita com agulhas de calibre mais grosso tem mais chances de ocorrer esse fenômeno e geralmente ocorre em coleta de tecidos mais profundos. A taxa dessa complicação é de 0,009\%. 


\subsubsection{Materiais Utilizados e Técnica}

Os materiais utilizados para a coleta da PAAF são uma agulha fina (18G a 25G), um dispositivo a vácuo, seringa descartável e lâminas para esfregaço citológico (Kline, 1988; Amedee; Dhurandhar, 2001).

Após antissepsia da região, a anestesia local pode ou não ser utilizada a critério clínico (Kline, 1988; Fitzhugh et al., 2009). A agulha é introduzida na lesão, o vácuo é feito e se mantém a pressão, realizando movimentos de vai e vem. Enquanto uma mão segura todo o dispositivo a outra fixa a lesão (Kline, 1988; Amedee; Dhurandhar, 2001). A PAAF pode ser feita sem a presença do dispositivo a vácuo, usando somente a seringa e a agulha, mas com a mesma técnica de coleta descrita acima (Kline, 1988; Fulciniti et al., 1997). Há também uma técnica de coleta sem aspiração, onde a agulha é introduzida na lesão e os movimentos de vai e vem são realizados, não havendo a pressão a vácuo. Alguns trabalhos recomendam essa técnica para se coletar mais material, principalmente se o conteúdo da lesão for sólido, evitando assim contaminação por sangue ou outros fluidos (Millar et al., 1990).

A PAAF pode ser realizada por um patologista, um clínico bem treinado ou um grupo de clínicos especializados como um radiologista, um clínico e um patologista e o material pode ser coletado mais de uma vez, dependendo da lesão (Kline, 1988; Amedee; Dhurandhar, 2001).

\subsubsection{Esfregaço e Fixação}

Após o material ser coletado, a seringa juntamente com a agulha é retirada do sistema a vácuo e o material colocado próxima a parte fosca da lâmina. Com outra lâmina em posição de $45^{\circ}$ sobre a superfície do material coletado, se arrasta o material e o esfregaço é feito (Kline, 1988; Amedee; Dhurandhar, 2001).

As lâminas podem ser fixadas em álcool, com sprays prontos e distribuídos comercialmente ou secas ao ar, de acordo com a técnica de coloração que será 
realizada posteriormente (Kline, 1988; Millar et al., 1990; Amedee; Dhurandhar, 2001).

Uma técnica que pode ser realizada com a amostra coletada pela PAAF é o "Cell Block", que consiste em aspirar uma solução salina balanceada ou solução de formol e centrifugar essa solução, se o material for sólido. Se o material for líquido, pode ser colocado diretamente no formol e depois centrifugado. Após isso, o material sedimentado é emblocado em parafina e são feitas lâminas convencionais, como num corte histológico (Kline, 1988; Wakely; Kneisl, 2000).

\subsubsection{Colorações Utilizadas}

As colorações mais utilizadas na PAAF são (Lever et al., 1995; Kline, 1988; Ansari; Derias, 1997; Amedee; Dhurandhar, 2001; Krafts; Pambuccian, 2011):

- Colorações tipo Romanowsky - Giemsa, May-Grünwald-Giemsa, WrightGiemsa (Diff-Quick ${ }^{\circledR}$ ou Panótico Rápido).

- Papanicolau

- Hematoxilina-Eosina

O primeiro pesquisador a empregar coloração em preparações citológicas foi Paul Elrich. Em 1882 empregou azul de metileno-eosina para descrever células de adenocarcinoma em fluidos pleural e de peritônio (Krafts; Pambuccian, 2011).

Söderström, Franzén e Lopes-Cardoso eram clínicos especializados em hematologia e utilizaram a coloração de Romanowsky para visualizar suas preparações citológicas (Krafts; Pambuccian, 2011).

As colorações do tipo Romanowsky são realizadas após as lâminas secas ao ar. Já as colorações de Papanicolau e Hematoxilina-Eosina, são realizadas após as lâminas serem fixadas em álcool (Lever et al., 1995; Kline, 1988; Ansari; Derias, 1997; Amedee; Dhurandhar, 2001; Krafts; Pambuccian, 2011).

A amostra seca ao ar faz com que as células aumentem de tamanho, influenciando na cromatina nuclear, transformando-as em mais condensadas e hiper 
cromáticas. Após a técnica de coloração do tipo Romanowsky, ocorre uma melhor estimativa das células e seus núcleos, fazendo com que detalhes citoplasmáticos sejam vistos. Nessa técnica, também é muito útil a visualização de microrganismos (Ansari; Derias, 1997; Krafts; Pambuccian, 2011).

A amostra fixada em álcool, diminui o tamanho celular, mas preserva seus contornos e estrutura. Na coloração de Papanicolau, podemos visualizar melhor os detalhes nucleares e queratinização das células. Já na coloração de hematoxilinaeosina, podemos ver grânulos e detalhes citoplasmáticos, assim como a queratinização das células (Ansari; Derias, 1997; Krafts; Pambuccian, 2011).

Nos "Cell Blocks", a técnica de coloração padrão utilizada é a de Hematoxilina-Eosina (Kline, 1988; Wakely; Kneisl, 2000).

Outras colorações podem ser empregadas nas lâminas de PAAF e nos "Cell Blocks", como as técnicas de coloração para bactérias e técnicas de imunocitoquímica, respectivamente (Fitzhugh et al., 2009b).

Young et al. (1981), descreve que patologistas acostumados com colorações de Papanicolau e Hematoxilina-Eosina, se sentem mais confortáveis com amostras fixadas em álcool. E patologistas mais acostumados com a hematologia, que usam colorações do tipo Romanowsky, preferem as amostras secas ao ar.

\subsubsection{Exames Auxiliares}

Os exames auxiliares mais utilizados com a PAAF são (Millar et al., 1990; Cha et al., 1997; Krishnamurthy, 1997; Erzöz et al., 1998; Tarantino et al., 1998; Skoog et al., 1999; Wakely; Kneisl, 2000; Postema et al., 2004; Vargas et al., 2007; Fitzhugh et al., 2009a; Moatamed et al., 2009; Bagga et al., 2010; Cozollino et al., 2014; Kalograki et al., 2014):

- Imaginológicos: como o ultrassom, que pode guiar a PAAF tanto em lesões mais profundas como as palpáveis 
- Testes auxiliares: imunocitoquímica, citometria de fluxo, biologia molecular, cultura de microrganismos, hibridização in-situ, PCR. Esses testes auxiliam na deteç̧ão e diagnóstico de lesões malignas e benignas.

\subsubsection{Critérios Diagnósticos}

O patologista, ao visualizar a lamina de PAAF deve reconhecer populações celulares que determinam um padrão de malignidade ou de benignidade (Kline, 1988; Koss, 1992).

\subsubsection{Sensibilidade, Especificidade e Acurácia}

Podemos definir sensibilidade, especificidade e acurácia da seguinte maneira (Loong, 2003):

- Sensibilidade - capacidade de um teste em identificar indivíduos com doença

- Especificidade - capacidade de um teste em identificar indivíduos sem doença

- Acurácia - capacidade de um teste dar diagnóstico preciso de uma determinada doença.

Trott definiu em um de seus trabalhos que, em PAAF, sensibilidade é a capacidade do teste de identificar lesões malignas e especificidade é a capacidade do teste de identificar lesões benignas (Florentine et al., 2006; Santos et al., 2011). A acurácia pode também ser definida como a relação entre a somatória de verdadeiros benignos e de verdadeiros malignos por todos os casos confirmados em um teste (Anand M et al., 2004). 


\subsubsection{Região de Cabeça e Pescoço, Glândulas Salivares e Cavidade Oral}

Como descrito anteriormente, a PAAF é muito utilizada em Região de cabeça e pescoço, principalmente em Glândulas Salivares Maiores, Linfonodos e Tireóide (Koss, 1979b; Kline, 1988; Koss, 1992; Fulciniti et al., 1997; Pisharodi, 1997; Acre et al., 1999; Anand; Brockie, 1999; Cohen et al., 2004; Carrillo et al., 2009; Fitzhugh et al., 2009; Ashraf et al., 2014).

Em cavidade oral, a PAAF ainda é pouco utilizada, sendo seus trabalhos relatos de casos em lesões intra ósseas (August et al., 1999; Gupta et al., 2009; Fonseca et al., 2013), tumores odontogênicos (Stone et al., 1998; Blocklage et al., 1997; Choudhury et al., 2000; Saran et al., 2000; Kumar et al., 2002; Tsamis et al., 2002; Vargas et al., 2007; Dereci et al., 2011; Kaliamoorthy et al., 2013), lesões de glândulas salivares menores (Netto et al., 2008) e outras regiões orais (Barnard et al., 1993; Domanski; Akerman, 1998; Shah et al., 1999; Ashraf et al., 2010; Fitzhugh et al., 2009; Cozzolino et al., 2014) .

Há alguns trabalhos relatando sua importância no diagnóstico de lesões intraorais e cavidade orofaríngea, exaltando sua sensibilidade, especificidade e acurácia (Castelli et al., 1993; Saleh et al., 2008; Santos et al., 2011).

A técnica da PAAF é a mesma descrita para os outros órgãos (Kline, 1988; Millar et al., 1990; Fulciniti et al., 1997; Amedee; Dhurandhar, 2001; Fitzhugh et al., 2009), assim como o uso de exames auxiliares (Millar et al., 1990; Cha et al., 1997; Krishnamurthy, 1997; Erzöz et al., 1998; Tarantino et al., 1998; Skoog et al., 1999; Wakely; Kneisl, 2000; Postema et al. 2004; Vargas et al., 2007; Fitzhugh et al., 2009; Moatamed et al., 2009; Bagga et al., 2010; Cozollino et al., 2014; Kalograki et al., 2014).

As vantagens mais descritas em cavidade oral são o uso da técnica para diagnóstico pre-operatório, acompanhamento clínico, evitar danos a estruturas nobres dessa região e baixo risco de infecção (Castelli et al., 1993; Saleh et al., 2008).

As limitações mais descritas nessa região são o pequeno espaço para se fixar a lesão, com consequente dificuldade de realizar os movimentos de vai e vem, 
causando então, material insuficiente na amostra para ser analisada (Castelli et al., 1993; Saleh et al., 2008).

As complicações mais descritas da técnica nessa região, são as de ordem local (Ansari; Derias, 1997; Fulciniti et al., 1997; Mighell; High, 1998, Tyagi; Dey, 2014).

As colorações mais utilizadas em PAAF na cavidade oral, são as mesmas de outras regiões, as colorações tipo Romanowsky para lâminas secas ao ar e as colorações de Papanicolau e Hematoxilina-Eosina, para as lâminas fixadas em álcool (Barnard et al., 1993; Castelli et al., 1993; Domanski; Akerman, 1998; August et al., 1999; Stone et al., 1998; Blocklage et al., 1997; Shah et al., 1999; Choudhury et al., 2000; Saran et al., 2000; Kumar et al., 2002; Tsamis et al., 2002; Vargas et al., 2007; Ashraf et al., 2010; Netto et al., 2008; Saleh et al., 2008; Fitzhugh et al., 2009; Gupta et al., 2009; Dereci et al., 2011; Santos et al., 2011; Fonseca et al., 2013; Kaliamoorthy et al., 2013; Cozzolino et al., 2014). 


\section{PROPOSIÇÃO}

Avaliar a sensibilidade, especificidade e acurácia da PAAF em diferentes técnicas de coloração, para lesões nodulares de cavidade oral e região de cabeça e pescoço. 


\section{CASUÍSTICA E MÉTODOS}

\subsection{CASUÍSTICA}

Para a pesquisa foram selecionados 46 pacientes consecutivamente que procuraram a clínica da Disciplina de Estomatologia Clínica da FOUSP, portadores de lesões nodulares em cavidade oral e região de cabeça e pescoço.

Como critérios de inclusão foram selecionados pacientes de ambos os sexos, todas as etnias, acima dos 5 anos de idade, sem restrição de comorbidades e que foram realizadas PAAF com confirmação diagnóstica pela biópsia.

Como critérios de exclusão da pesquisa estão os pacientes abaixo dos 5 anos de idade e pacientes que foram somente submetidos a PAAF sem confirmação diagnóstica pela biópsia.

Dos 46 pacientes estudados, 39 foram avaliados para a comparação das três técnicas de coloração. 7 pacientes não foram incluídos na amostra pois possuíam lâminas somente coradas pelas técnicas de Papanicolau e Hematoxilina-Eosina.

\subsection{COMITÊ DE ÉTICA}

Após a aprovação do projeto pelo Comitê de Ética em Pesquisa com Parecer de Aprovação Protocolo 61/11 CAAE 0069.0.017.000-11 (Anexo A), os pacientes que concordaram em participar da pesquisa após leitura, assinaram o termo de Consentimento Livre e Esclarecido (Anexo B). 


\subsection{MÉTODO}

Após anamnese, exame clínico e estabelecimento de diagnóstico diferencial e assinatura do Termo de Consentimento Livre e Esclarecido, os pacientes que possuíam lesões em cavidade oral e região de cabeça e pescoço (dentro dos limites de atuação da Odontologia) foram preparados para a realização da PAAF e posteriormente, para a realização de biópsia incisional ou excisional, como padrão ouro .

A coleta dos dados foi feita em 31 meses e a análise dos dados e redação final do estudo em 5 meses, dando um total de 36 meses.

Não houve necessidade de grupo controle, pois foi usado um método comparativo entre o resultado proveniente de três técnicas de coloração com 0 o resultado final do Anátomo Patológico.

\subsection{TÉCNICA DE COLETA DA PAAF}

Para a realização da PAAF foi utilizada uma pistola tipo Franzen (Medpej ${ }^{\circledR}$ ), acoplada a uma seringa de $20 \mathrm{ml}$, descartável, agulhas de 23G a 25G, lâminas de vidro para microscopia, porta lâminas para citologia esfoliativa, álcool $96^{\circ} \mathrm{GL}$ e formol para a fixação de material de conteúdo líquido.

O procedimento foi realizado de acordo com a técnica descrita por Zadjicek (Kline, 1988; Fulciniti et al., 1997; Santos et al., 2011) onde primeiramente o campo operatório é preparado sendo feita sua assepsia, com administração de anestésico local ou não. Com uma das mãos se imobiliza a lesão e com outra se segura o dispositivo. Após isso, a agulha é introduzida na lesão, fazendo sucção do material com movimentos penetrantes em várias direções a fim de colher o máximo de material para o esfregaço. É desfeita então a pressão negativa e a agulha é retirada da lesão. A seringa é retirada da pistola e a agulha da seringa. A maior parte do material coletado está na agulha, portanto, após a remoção da agulha, a seringa 
então é preenchida de ar, a agulha novamente introduzida na seringa e próximo a superfície da lâmina que será realizado o esfregaço o material é depositado.

O material foi depositado em 6 lâminas e depois foi realizado o método de esfregaço comum. Em uma única etapa o material é depositado próximo a parte fosca da lâmina de vidro, outra lâmina é posicionada sobre a lâmina e o material é então arrastado. Posteriormente 2 lâminas foram secas ao ar e coradas com pelo método de Panótico e 4 lâminas foram fixadas em álcool $96^{\circ} \mathrm{GL}$ e enviadas a disciplina de Patologia Oral da FOUSP, com relatório anexo e diagnóstico diferencial e foram coradas pelo método de Hematoxilina-Eosina e de Papanicolau.

\subsection{TÉCNICA DE COLORAÇÃO}

As técnicas de coloração utilizadas para as lâminas de PAAF foram o Panótico (NewProv ${ }^{\circledR}$ ), o Papanicolau e a Hematoxilina-Eosina e nas lâminas de Anátomo Patológico, a Hematoxilina-Eosina.

\subsection{ANÁLISE DO MATERIAL}

As lâminas de PAAF foram avaliadas por um patologista sem visualização prévia do anátomo patológico obtido pela biópsia, porém todas foram encaminhadas com um relatório com os dados do paciente e o diagnóstico clínico da lesão. As lâminas de anátomo patológico foram visualizadas pelo mesmo patologista após a emissão do laudo de PAAF.

Os resultados das seis lâminas de PAAF e das lâminas do anátomo patológico foram comparados, a fim de se obter resultados que nos demonstrassem sensibilidade, especificidade e acurácia do método em diferentes colorações.

Os dados foram coletados através dos prontuários dos pacientes que foram atendidos pela Disciplina de Estomatologia Clínica na Clínica Odontológica da FOUSP e tabulados eletronicamente. 


\subsection{ANÁLISE DOS RESULTADOS}

Foi feito o cálculo de sensibilidade, especificidade e acurácia em cada grupo de coloração estudados na PAAF, comparando seus laudos com os respectivos laudos de Anátomo Patológico. 


\section{RESULTADOS}

Após análise dos prontuários e tabulação de dados, 56 pacientes foram submetidos a PAAF e desses, 46 pacientes preencheram os critérios de inclusão propostos, entrando na casuística do presente estudo.

Após a coleta do material, foram produzidas 262 lâminas de PAAF. Dessas, 234 lâminas de PAAF passaram pelo processo de coloração pelo método de Panótico, Papanicolau e Hematoxilina-Eosina e 28 lâminas passaram pelo processo de coloração pelo método de Papanicolau e de Hematoxilina-Eosina.

\subsection{IDADE, GÊNERO E ETINIA}

As idades dos pacientes variaram de 11 a 73 anos, com uma média de idade de 35,84 anos. A distribuição por gênero foi de 23 homens (50\%) e 23 mulheres (50\%), dos quais as etnias eram de 17 melanodermas (36,9\%) e 29 leucodermas $(63,1 \%)$.

A faixa etária mais incidente foi a de 10-20 (12 casos $-26,2 \%$ ), seguida das incidências de $40-50$ (10 casos - 21,7\%), 20-30 (7 casos - 15,2\%) e 30-40 (7 casos - 15,2\%), 50-60 ( 5 casos - 10,9\%), 60-70 (4 casos - 8,7\%) e 70-80 ( 1 caso -2,1\%). Todos os dados coletados estão demonstrados nos gráficos 5.1, 5.2 e 5.3.

\section{Gênero}

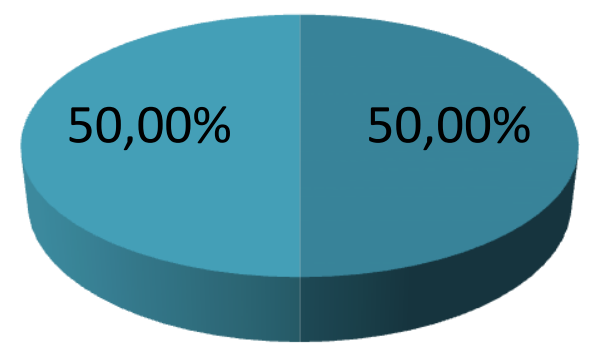

- Homens

Mulheres

Gráfico 5.1 - Distribuição por gênero dos 46 pacientes 


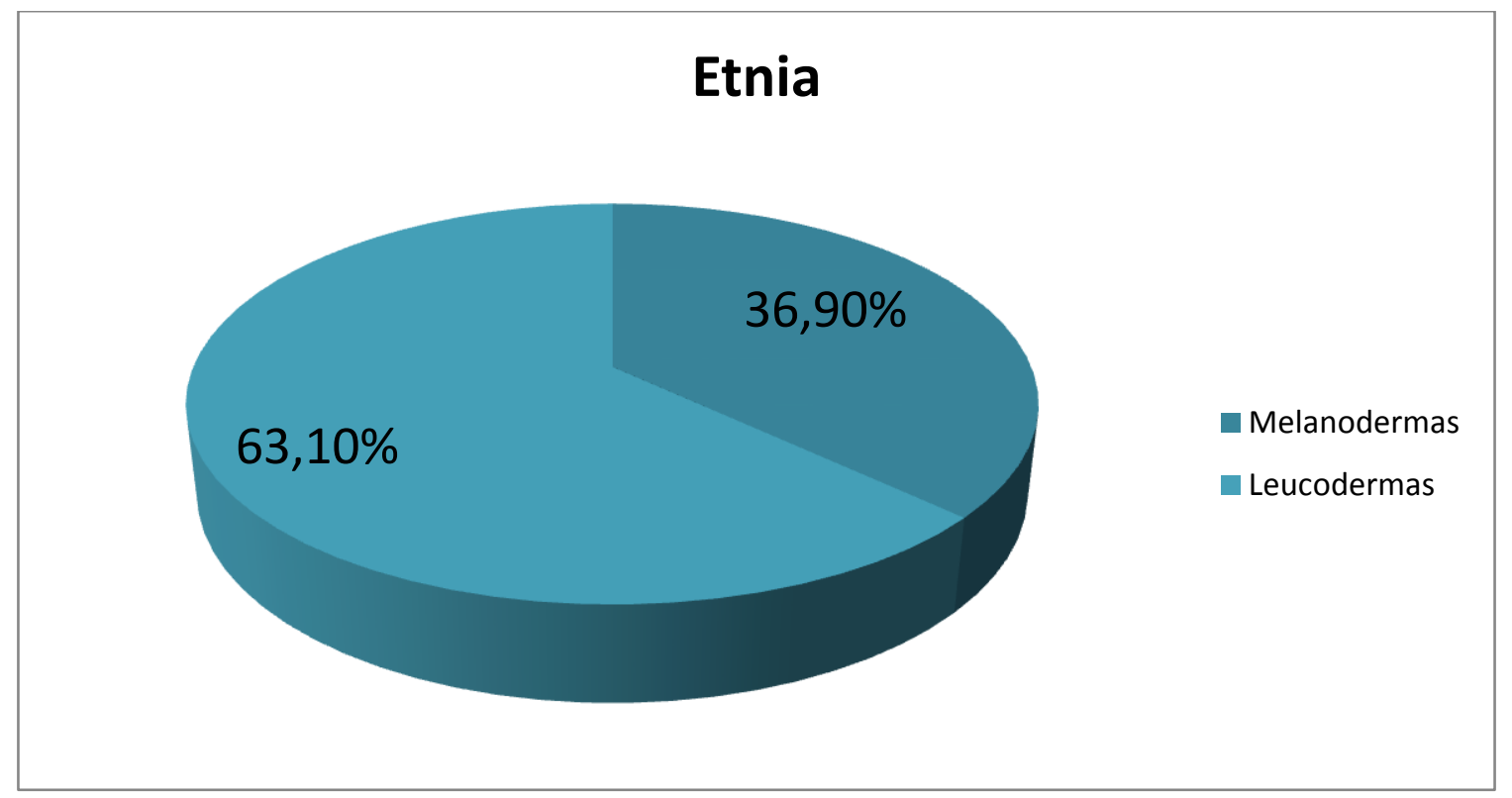

Gráfico 5.2 - Distribuição dos 46 pacientes por etnia

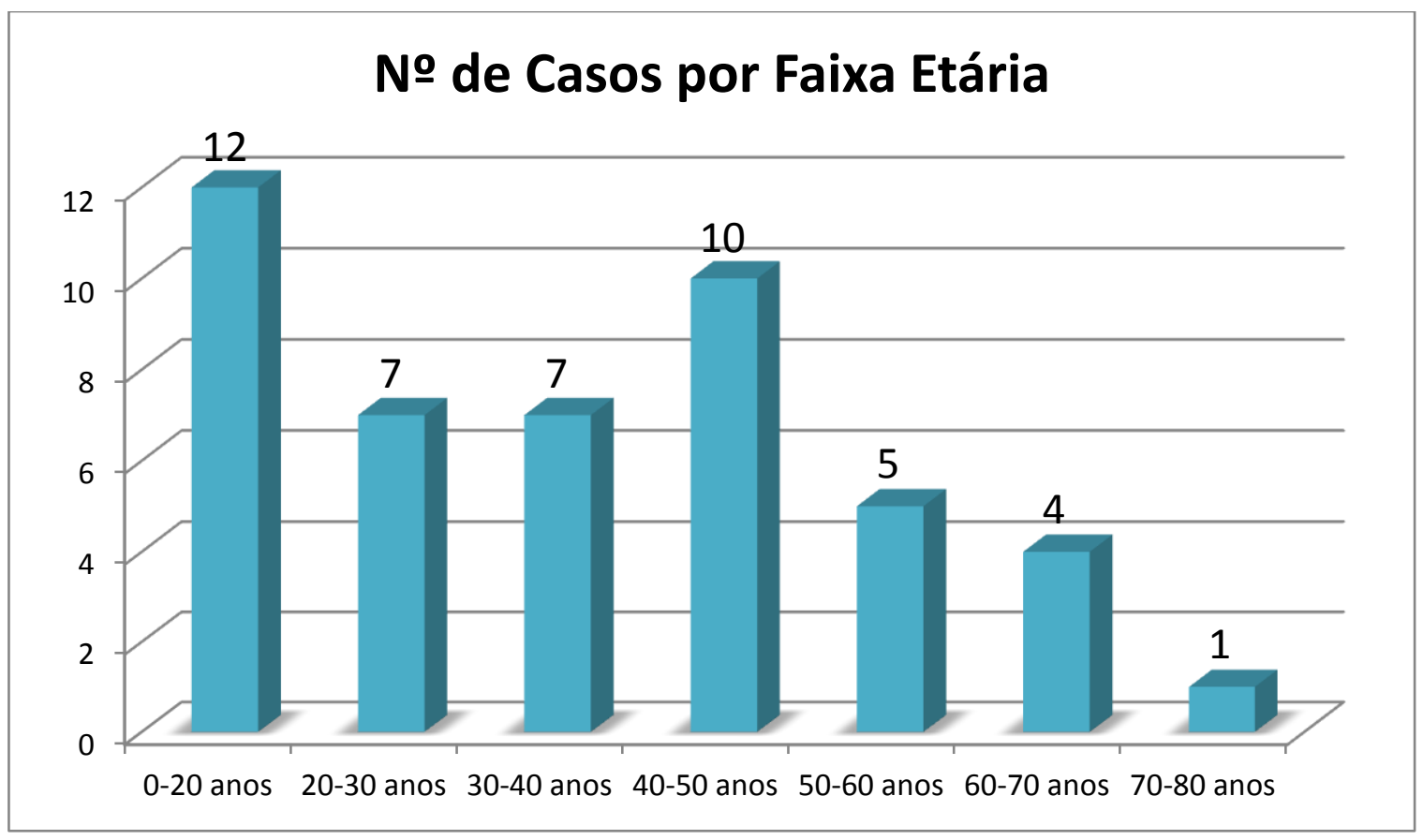

Gráfico 5.3 - Distribuição do número casos por faixa etária 


\subsection{TIPOS DE LESÃO}

Dos 46 pacientes examinados e submetidos a PAAF, 27 pacientes apresentavam Lesões Benignas (LB) que incluíram Cistos de Origem Odontogênica, Cistos de Origem Inflamatória e Neoplasias Benignas propriamente ditas, 8 pacientes apresentavam Neoplasias Malignas (NM), 2 pacientes apresentavam Lesões Proliferativas Não Neoplásicas (LPNN), 6 pacientes apresentavam Processos Inflamatórios (PI) e 2 pacientes apresentavam Cistos Reacionais (LR). Esses dados estão representados no gráfico 5.3.

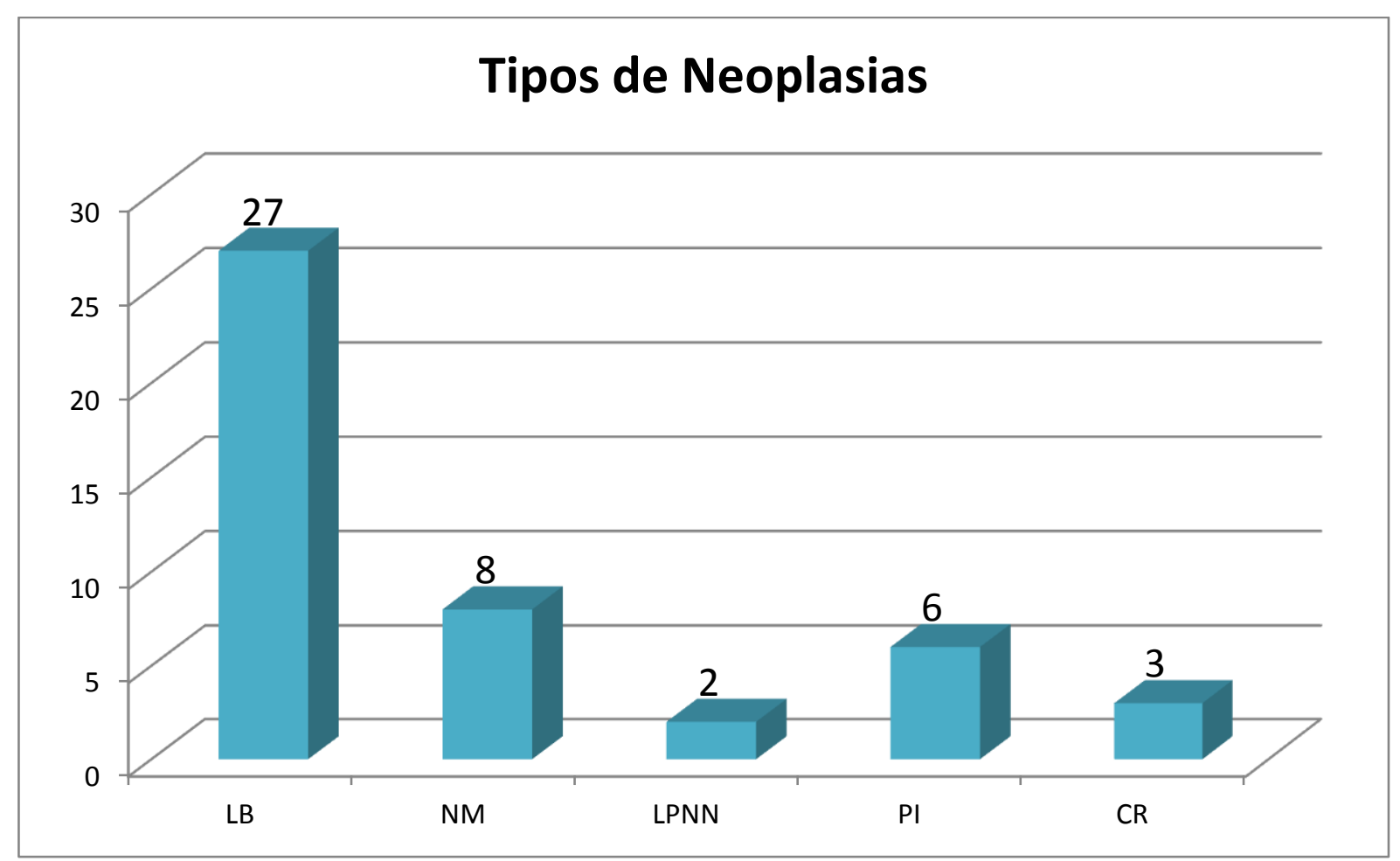

Gráfico 5.4 - Tipos de neoplasias presentes nos 46 pacientes estudados 


\subsection{CÁLCULO DA SENSIBILIDADE, ESPECIFICIDADE E ACURÁCIA}

Os dados foram coletados a partir dos prontuários dos pacientes estudados na amostra e tabulados eletronicamente pelo Microsoft Excel ${ }^{\circledR}$ em uma tabela com identificação, idade, gênero, etnia, hipótese diagnóstica, resultado da PAAF na coloração Panótico, Papanicolau e Hematoxilina-Eosina e resultado do Anátomo Patológico.

Os cálculos de sensibilidade, especificidade e acurácia foram feitos segundo as definições de Trott (Florentine BD et al., 2006; Santos et al., 2011) onde a sensibilidade é a capacidade do teste de identificar lesões malignas e a especificidade é a capacidade do teste de identificar leões benignas. As lesões benignas consideradas foram as neoplasias benignas, as lesões proliferativas não neoplásicas, os processos inflamatórios e as lesões reacionais. A acurácia do teste foi calculada como a quantidade dos resultados da PAAF semelhantes aos resultados do Anátomo Patológico.

O cálculo da sensibilidade, da especificidade e da acurácia foram feitos separadamente para cada tipo de coloração.

Nesse estudo foram produzidas um total de 262 lâminas de PAAF. Para comparação das técnicas de coloração, 234 lâminas foram coradas pelas técnicas de Panótico, Papanicolau e Hematoxilina-Eosina e entram no cálculo de sensibilidade, especificidade e acurácia do estudo. As 28 lâminas remanescentes, foram coradas somente pelas técnicas de Papanicolau e Hematoxilina-Eosina, e sua sensibilidade, especificidade e acurácia foram calculadas separadamente, não entrando na casuística do estudo.

Dos 46 pacientes estudados, 39 foram avaliados para a comparação das três técnicas de coloração. Desses 39 pacientes, 32 apresentavam lesões benignas e 7 apresentavam lesões malignas. Os 7 pacientes não incluídos na amostra apresentavam 6 lesões benignas e 1 lesão maligna.

Na coloração de Panótico, foram diagnosticadas 19 lesões benignas, 2 lesões malignas, 13 casos foram inconclusivos e 5 casos não possuíam material suficiente para análise. Destes casos inconclusivos, 5 eram de lesões malignas, 8 de lesões 
benignas. O resultado da PAAF nessa coloração foi compatível com o resultado do Anátomo Patológico em 4 casos.

$\mathrm{Na}$ coloração de Papanicolau, foram diagnosticadas 23 lesões benignas, 5 lesões malignas, 9 casos inconclusivos e 2 casos não possuíam material suficiente para a análise. Destes casos inconclusivos, 2 eram de lesões malignas, 7 eram de lesões benignas. O resultado da PAAF nessa coloração foi compatível com 0 resultado do Anátomo Patológico em 7 casos.

$\mathrm{Na}$ coloração de Hematoxilina-Eosina, foram diagnosticadas 23 lesões benignas, 5 lesões malignas, 6 casos inconclusivos e 5 casos não possuíam material suficiente para a análise. Destes casos inconclusivos, 2 casos eram de lesões malignas, 4 casos eram de lesões benignas. O resultado da PAAF nessa coloração foi compatível com o resultado do Anátomo Patológico em 6 casos.

Nessa amostra estudada, não houve casos falso-negativos ou falso-positivos, em nenhuma das três colorações. Para fins de estudo estatístico, os casos inconclusivos provenientes de lesões malignas foram considerados como falsonegativos e os casos inconclusivos provenientes de lesões benignas foram considerados falso-positivos. Os casos inconclusivos de cada coloração, assim como a relação de casos diagnosticados em cada técnica estão presentes no gráfico 5.4 e tabelas 5.1, 5.2 e 5.3, respectivamente.

\section{Inconclusivos}

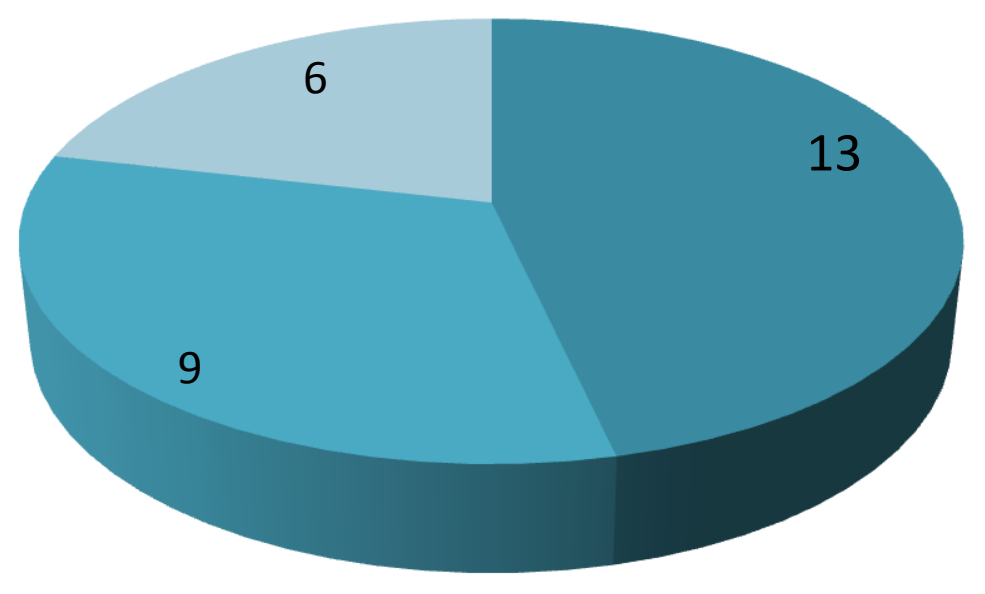

- Panótico

Papanicolau

Hematoxilina-Eosina

Gráfico 5.5 - Número de casos inconclusivos presentes nas três colorações 
Tabela 5.1 - Total de lesões diagnosticadas pela PAAF pelo método de Panótico

\begin{tabular}{lcc}
\hline Resultados & PAAF & Anátomo Patológico \\
\hline Benignas & 19 & 32 \\
Malignas & 2 & 7 \\
Total & 21 & 39 \\
\hline
\end{tabular}

Tabela 5.2 - Total de lesões diagnosticadas pela PAAF pelo método de Papanicolau

\begin{tabular}{lcc}
\hline Resultados & PAAF & Anátomo Patológico \\
\hline Benignas & 23 & 32 \\
Malignas & 5 & 7 \\
Total & 28 & 39 \\
\hline
\end{tabular}

Tabela 5.3 - Total de lesões diagnosticadas pela PAAF pelo método de Hematoxilina-Eosina

\begin{tabular}{lcc}
\hline Resultados & PAAF & Anátomo Patológico \\
\hline Benignas & 23 & 32 \\
Malignas & 5 & 7 \\
Total & 28 & 39 \\
\hline
\end{tabular}

O cálculo da acurácia, sensibilidade e especificidade para as três colorações foram calculados pelas seguintes fórmulas (Santos, 2010):

$$
\begin{aligned}
\text { Acurácia } & =\frac{\text { Total de } P A A F \text { compativel }}{\text { Total de Biópsias-Inconclusivos }} \\
\text { Sensibilidade } & =\frac{\text { Verdadeiros malignos } P A A F}{\text { Verdadeiros malignos } P A A F+F N P A A F} \\
\text { Especificidade } & =\frac{\text { Verdadeiros benignos } P A A F}{\text { Verdadeiros benignos } P A A F+F P P A A F}
\end{aligned}
$$


Como foi dito anteriormente, para fins de estudo estatístico, os casos inconclusivos provenientes de lesões malignas foram considerados como falsonegativos e os casos inconclusivos provenientes de lesões benignas foram considerados falso-positivos. Para o cálculo da acurácia, todos os casos inconclusivos e sem material para a análise foram excluídos da amostra.

$\mathrm{Na}$ coloração de Panótico, o cálculo da sensibilidade foi de 28,6\%, a especificidade foi de $76 \%$ e a acurácia do teste foi de $15,4 \%$. Os dados utilizados no cálculo de sensibilidade e especificidade estão demonstrados na tabela 5.4.

Tabela 5.4 - Cálculo de sensibilidade e especificidade no método de coloração por Panótico

\begin{tabular}{lcc}
\hline Resultados & Malignos Anátomo Patológico & Benignos Anátomo Patológico \\
\hline Malignos PAAF & 2 & 8 \\
Benignos PAAF & 5 & 19 \\
\hline
\end{tabular}

Na coloração de Papanicolau, o cálculo da sensibilidade foi de 71,4\%, a especificidade foi de $76,7 \%$ e a acurácia do teste foi de $23,3 \%$. Os dados utilizados no cálculo de sensibilidade e especificidade estão demonstrados na tabela 5.5.

Tabela 5.5 - Cálculo de sensibilidade e especificidade no método de coloração por Papanicolau

\begin{tabular}{lcc}
\hline Resultados & Malignos Anátomo Patológico & Benignos Anátomo Patológico \\
\hline Malignos PAAF & 5 & 7 \\
Benignos PAAF & 2 & 23 \\
\hline
\end{tabular}

Na coloração de Hematoxilina-Eosina, o cálculo da sensibilidade foi de 71,4\%, a especificidade foi de $82,1 \%$ e a acurácia do teste foi de $28,6 \%$. Os dados utilizados no cálculo de sensibilidade e especificidade estão demonstrados na tabela 5.6

Tabela 5.6 - Cálculo de sensibilidade e especificidade no método de coloração por Hematoxilina-Eosina

\begin{tabular}{lcc}
\hline Resultados & Malignos Anátomo Patológico & Benignos Anátomo Patológico \\
\hline Malignos PAAF & 5 & 4 \\
Benignos PAAF & 2 & 23 \\
\hline
\end{tabular}


Comparando-se, portanto, as três colorações, na metodologia do presente estudo, temos:

- As colorações de Hematoxilina-Eosina e Papanicolau possuem a melhor taxa de sensibilidade $(71,4 \%)$, comparadas à coloração de Panótico $(28,6 \%)$.

- A coloração de Hematoxilina-Eosina apresenta a melhor especificidade $(82,1 \%)$ comparada à coloração de Papanicolau $(76,7 \%)$ e a coloração de Panótico (76\%).

- A coloração de Hematoxilina-Eosina apresenta a melhor acurácia $(28,6 \%)$ comparada à coloração de Papanicolau (23,3\%) e a coloração de Panótico $(15,4 \%)$.

Os dados utilizados na comparação final estão demonstrados na tabela 5.7.

Tabela 5.7 - Comparação das três técnicas de coloração de acordo com sua sensibilidade, especificidade e acurácia

\begin{tabular}{lccc}
\hline Resultados & Panótico & Papanicolau & Hematoxilina-Eosina \\
\hline Sensibilidade & $28,6 \%$ & $71,4 \%$ & $71,4 \%$ \\
Especificidade & $76 \%$ & $76,7 \%$ & $82,1 \%$ \\
Acurácia* & $15,4 \%{ }^{*}$ & $23,3 \%{ }^{*}$ & $28,6 \%{ }^{*}$ \\
\hline${ }^{*}$ Casos inconclusivos excluídos da amostra & &
\end{tabular}

Há diferença estatisticamente significativa na proporção de sensibilidade, especificidade e acurácia entre as diferentes técnicas de coloração (X2 13,27, $p=0,01$ ).

\begin{tabular}{|c|l|l|l|l|}
\hline \multicolumn{2}{|c|}{ Contingency } & & & \\
\cline { 3 - 5 } & & & & \\
\hline & & & & \\
\hline $\mathbf{1}$ & Table Analyzed & Data 1 & & \\
\hline $\mathbf{2}$ & & & & \\
\hline $\mathbf{3}$ & Chi-square & & & \\
\hline $\mathbf{4}$ & Chi-square, df & $13.27,4$ & & \\
\hline $\mathbf{5}$ & P value & 0.0100 & & \\
\hline $\mathbf{6}$ & P value summary & $*$ & & \\
\hline $\mathbf{7}$ & One- or two-sided & NA & & \\
\hline $\mathbf{8}$ & Statistically significant? (alpha<0.05) & Yes & & \\
\hline $\mathbf{9}$ & & & & \\
\hline $\mathbf{1 0}$ & Data analyzed & & & \\
\hline $\mathbf{1 1}$ & Number of rows & 3 & & \\
\hline $\mathbf{1 2}$ & Number of columns & 3 & & \\
\hline
\end{tabular}


Os 7 pacientes não incluídos na amostra apresentavam 6 lesões benignas e 1 lesão maligna.

$\mathrm{Na}$ coloração de Papanicolau foram diagnosticadas 5 lesões benignas, 1 lesão maligna e 1 caso inconclusivo, onde as lâminas não apresentavam material suficiente para análise. O resultado da PAAF nessa coloração foi compatível com o resultado do Anátomo Patológico em 3 casos.

$\mathrm{Na}$ coloração de Hematoxilina-Eosina foram diagnosticadas 5 lesões benignas, 1 lesão maligna e 1 caso inconclusivo, onde as lâminas não apresentavam material suficiente para análise. $O$ resultado da PAAF nessa coloração foi compatível com o resultado do Anátomo Patológico em 3 casos.

Os casos inconclusivos de cada coloração, assim como a relação de casos diagnosticados em cada técnica estão presentes no gráfico 5.5 e tabelas 5.8 e 5.9, respectivamente.

\section{Inconclusivos}

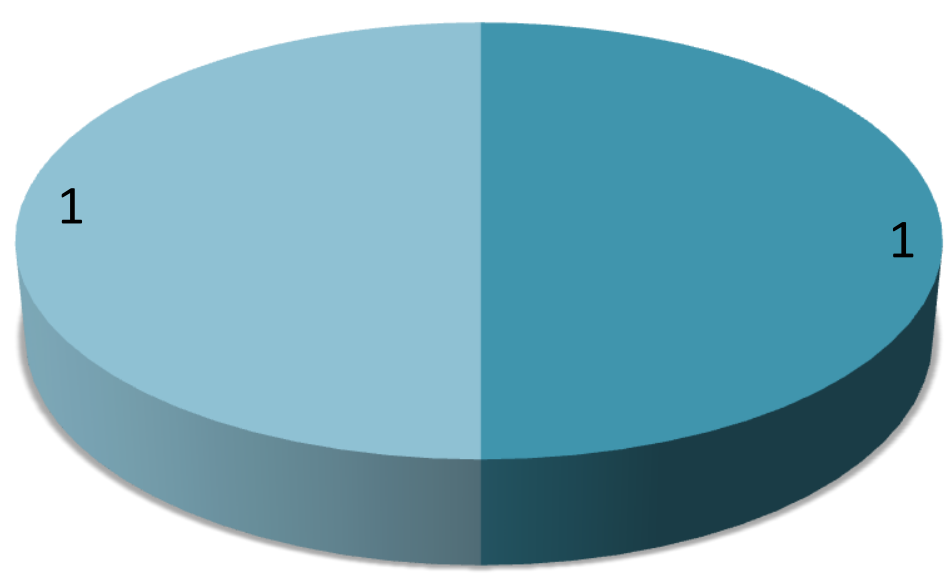

- Papanicolau

- Hematoxilina-Eosina

Gráfico 5.6 - Número de casos inconclusivos presentes nas duas colorações (7 casos não icluídos na amostra) 
Tabela 5.8 - Total de lesões diagnosticadas pela PAAF pelo método de Papanicolau

\begin{tabular}{lcc}
\hline Resultados & PAAF & Anátomo Patológico \\
\hline Benignas & 5 & 6 \\
Malignas & 1 & 1 \\
Total & 6 & 7 \\
\hline
\end{tabular}

Tabela 5.9 - Total de lesões diagnosticadas pela PAAF pelo método de Hematoxilina-Eosina

\begin{tabular}{lcc}
\hline Resultados & PAAF & Anátomo Patológico \\
\hline Benignas & 5 & 6 \\
Malignas & 1 & 1 \\
Total & 6 & 7 \\
\hline
\end{tabular}

O mesmo estudo estatístico foi empregado nesses 7 casos. Como não haviam falso-positivos ou falso-negativos, e nem casos de inconclusivos provenientes de lesões malignas ou benignas, e valor empregado foi zero. Os cálculos de sensibilidade, especificidade e acurácia foram realizados com as mesmas fórmulas empregadas acima, para as três colorações (Santos, 2010).

$$
\begin{aligned}
\text { Acurácia } & =\frac{\text { Total de } P A A F \text { compativel }}{\text { Total de } \text { Biópsias-Inconclusivos }} \\
\text { Sensibilidade } & =\frac{\text { Verdadeiros malignos } P A A F}{\text { Verdadeiros malignos PAAF+FN PAAF }} \\
\text { Especificidade } & =\frac{\text { Verdadeiros benignos } P A A F}{\text { Verdadeiros benignos PAAF+FP PAAF }}
\end{aligned}
$$


Na coloração de Papanicolau o cálculo da sensibilidade foi de $100 \%$, o de especificidade foi de $100 \%$ e a acurácia do teste foi de $50 \%$. Os dados utilizados nos cálculos de sensibilidade e especificidade estão demonstrados na tabela 5.10 .

Tabela 5.10 - Cálculo de sensibilidade e especificidade no método de coloração por Papanicolau

\begin{tabular}{lcc}
\hline Resultados & Malignos Anátomo Patológico & Benignos Anátomo Patológico \\
\hline Malignos PAAF & 1 & 0 \\
Benignos PAAF & 0 & 5 \\
\hline
\end{tabular}

Na coloração de Hematoxilina-Eosina o cálculo da sensibilidade foi de $100 \%$, o de especificidade foi de $100 \%$ e a acurácia do teste foi de $50 \%$. Os dados utilizados nos cálculos de sensibilidade e especificidade estão demonstrados na tabela 5.11 .

Tabela 5.11 - Cálculo de sensibilidade e especificidade no método de coloração por Hematoxilina-Eosina

\begin{tabular}{lcc}
\hline Resultados & Malignos Anátomo Patológico & Benignos Anátomo Patológico \\
\hline Malignos PAAF & 1 & 0 \\
Benignos PAAF & 0 & 5 \\
\hline
\end{tabular}

Comparando-se, portanto, as duas colorações, como feitas no presente estudo, mas sem validade para o mesmo, temos:

- As colorações de Papanicolau e Hematoxilina-Eosina possuem as mesmas taxas de sensibilidade (100\%)

- As colorações de Papanicolalou e Hematoxilina-Eosina possuem as mesmas taxas de especificidade (100\%)

- As colorações de Papanicolau e Hematoxilina-Eosina possuem as mesmas taxas de acurácia

Os dados utilizados na comparação, estão demonstrados na tabela 5.12. E todos os dados coletados estão presentes na tabela 5.13 . 
Tabela 5.12 - Comparação das duas técnicas de coloração de acordo com sua sensibilidade, especificidade e acurácia

\begin{tabular}{lcc}
\hline Resultados & Papanicolau & Hematoxilina-Eosina \\
\hline Sensibilidade & $100 \%$ & $100 \%$ \\
Especificidade & $100 \%$ & $100 \%$ \\
Acurácia $^{*}$ & $50 \%{ }^{*}$ & $50 \%{ }^{*}$ \\
\hline${ }^{*}$ Casos inconclusivos excluídos da amostra & &
\end{tabular}

Como exemplos podemos destacar alguns casos:

- CASO 1 - Paciente com suspeita clínica de Neoplasia Glandular Benigna

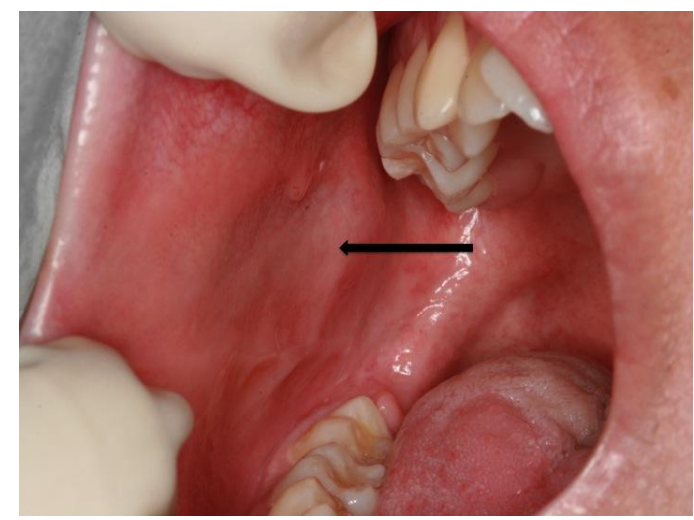

Figura 5.1 - Aspecto intra-oral lesão nodular em mucosa jugal, com hipótese diagnóstica de Neoplasia Glandular Benigna
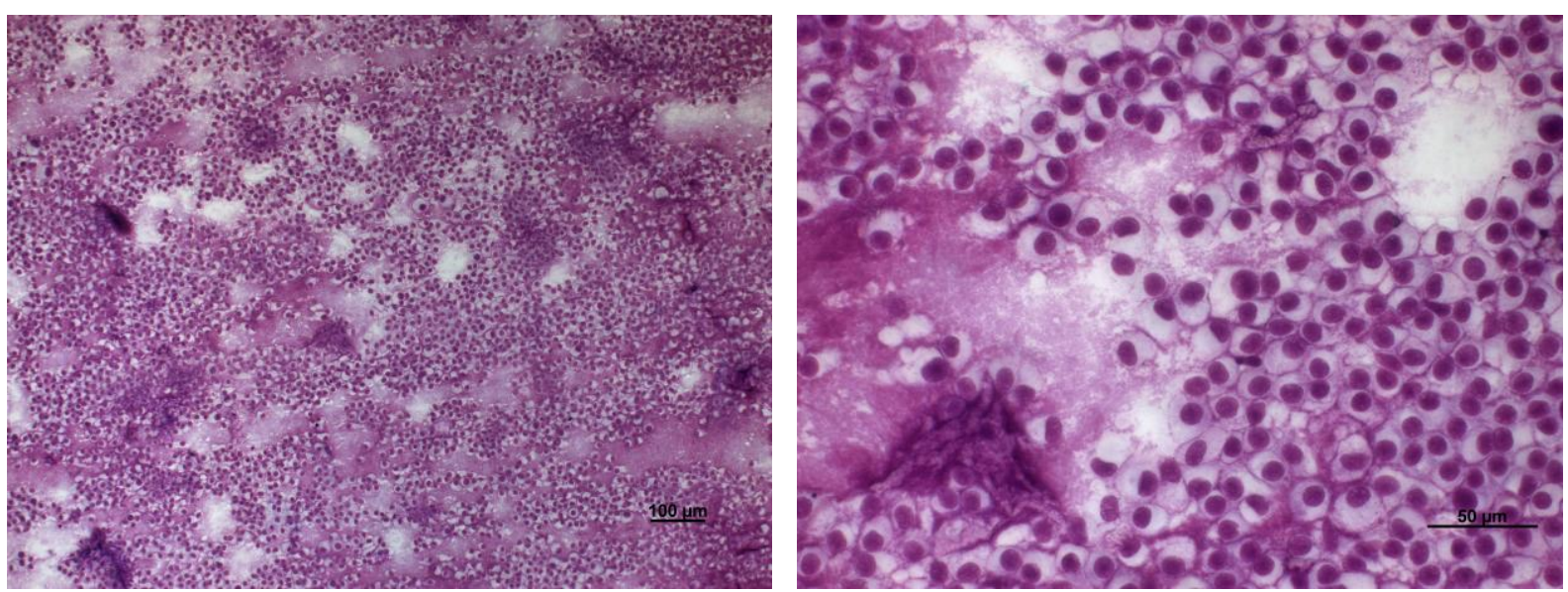

Fotomicrografia 5.1 - Presença de células plasmocitóides no esfregaço, em menor e maior aumento, com laudo sugestivo de adenoma pleomórfico, em coloração de Panótico 

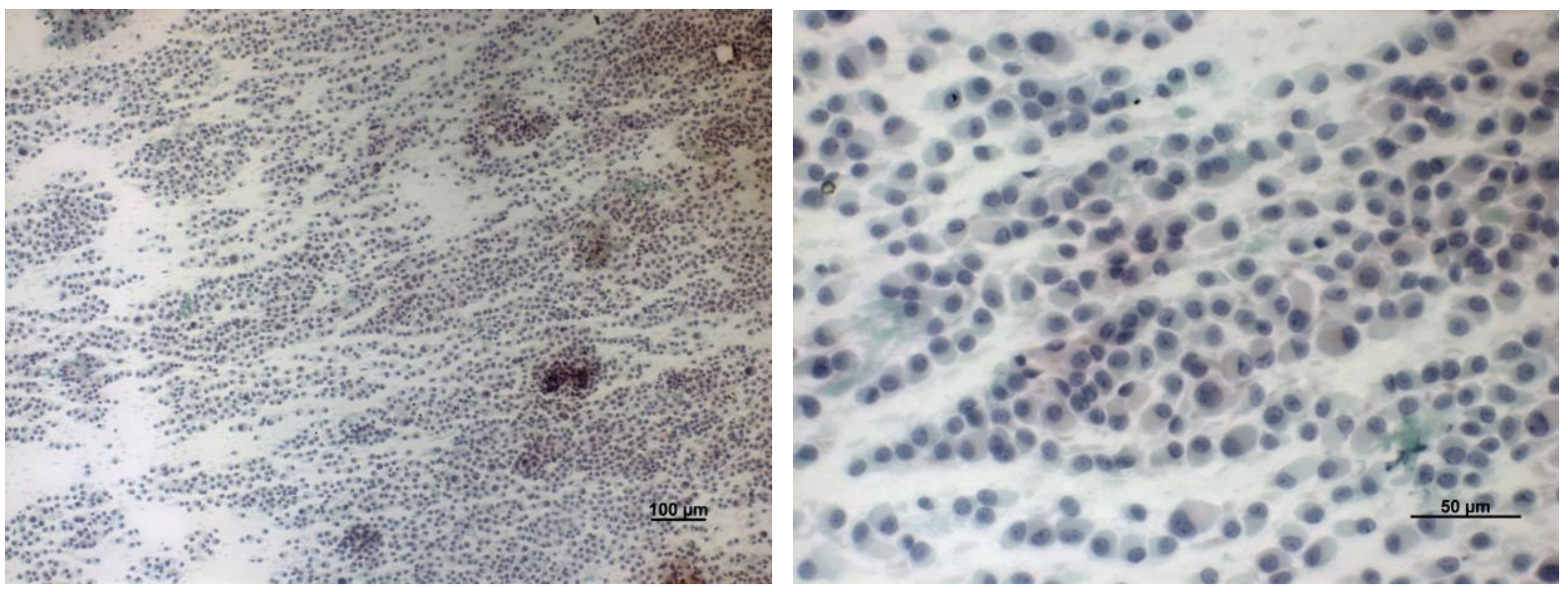

Fotomicrografia 5.2 - Presença de células plasmocitóides no esfregaço, em menor e maior aumento, com laudo sugestivo de adenoma pleomórfico, em coloração de Papanicolau
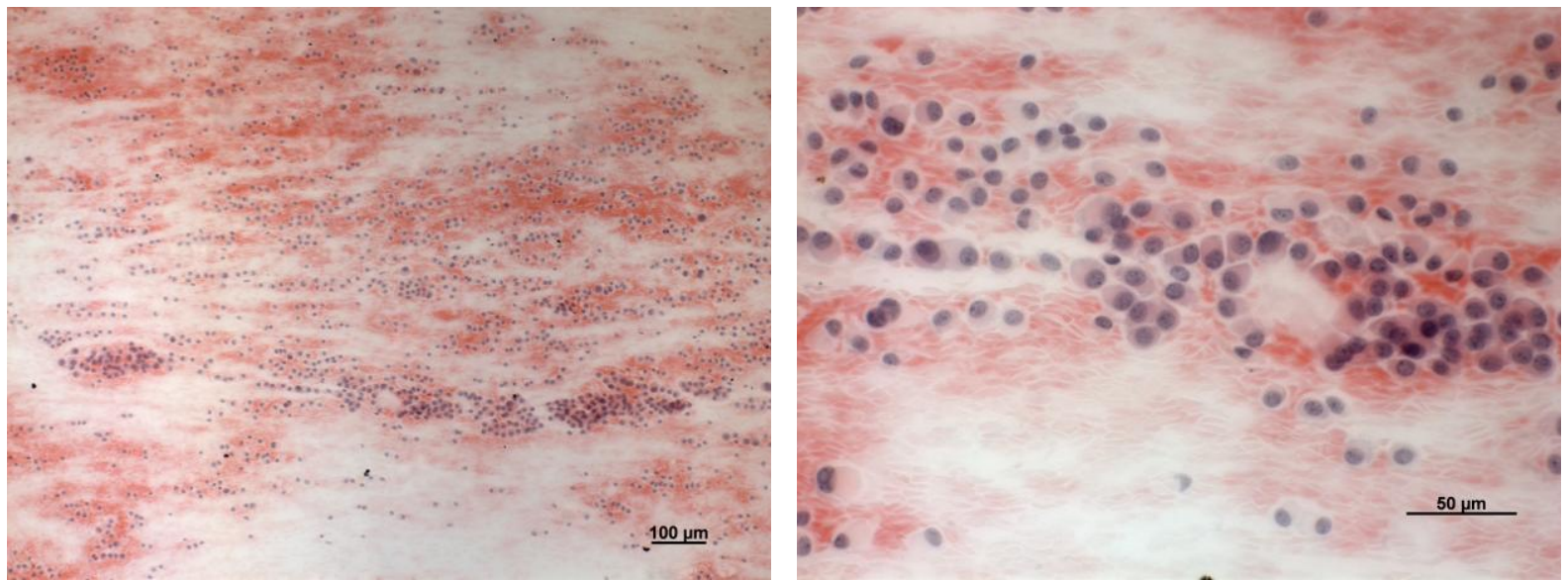

Fotomicrografia 5.3 - Presença de células plasmocitóides no esfregaço, em menor e maior aumento, com laudo sugestivo de adenoma pleomórfico, em coloração de Hematoxilina-Eosina
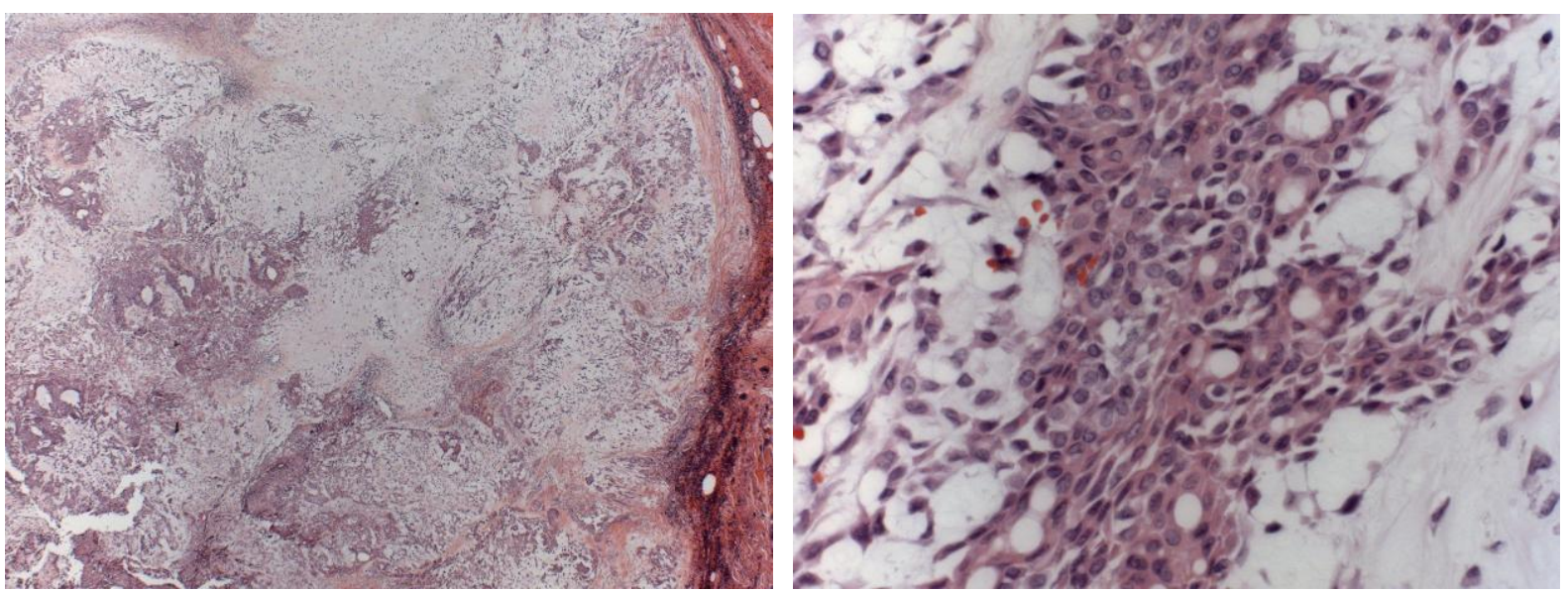

Fotomicrografia 5.4 - Corte histológico, com laudo definitivo de Adenoma Pleomórfico, em coloração de Hematoxilina-Eosina 
- Caso 2 - Paciente com suspeita clínica de Lesão Central de Células Gigantes

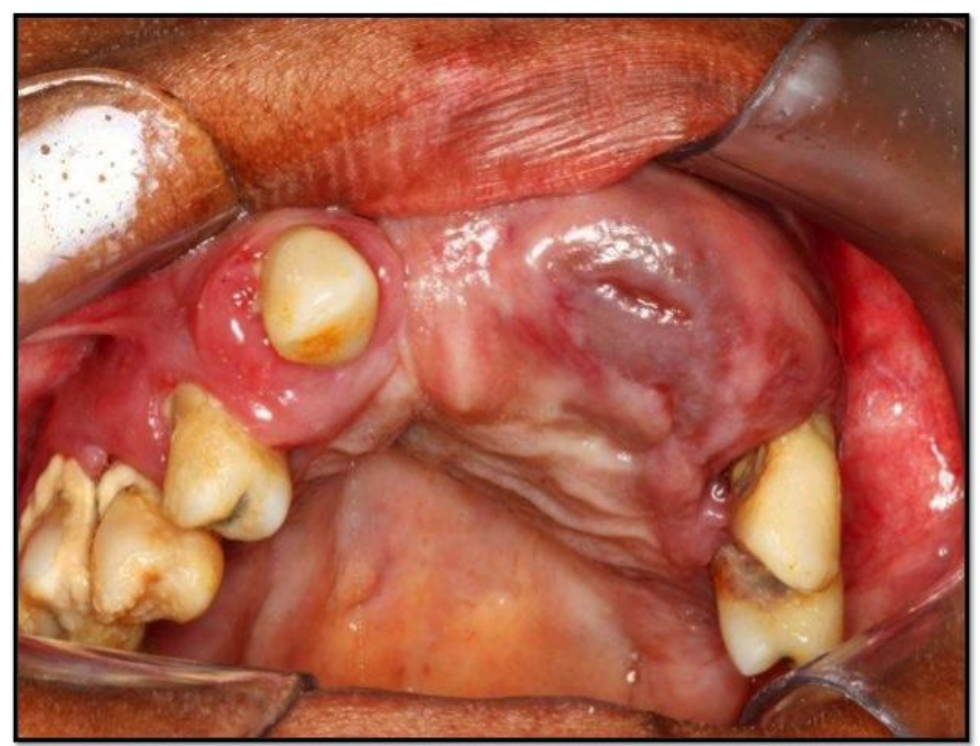

Figura 5.2 - Aspecto intra-oral de lesão nodular em região de maxila anterior, com hipótese diagnóstica de Lesão Central de Células Gigantes

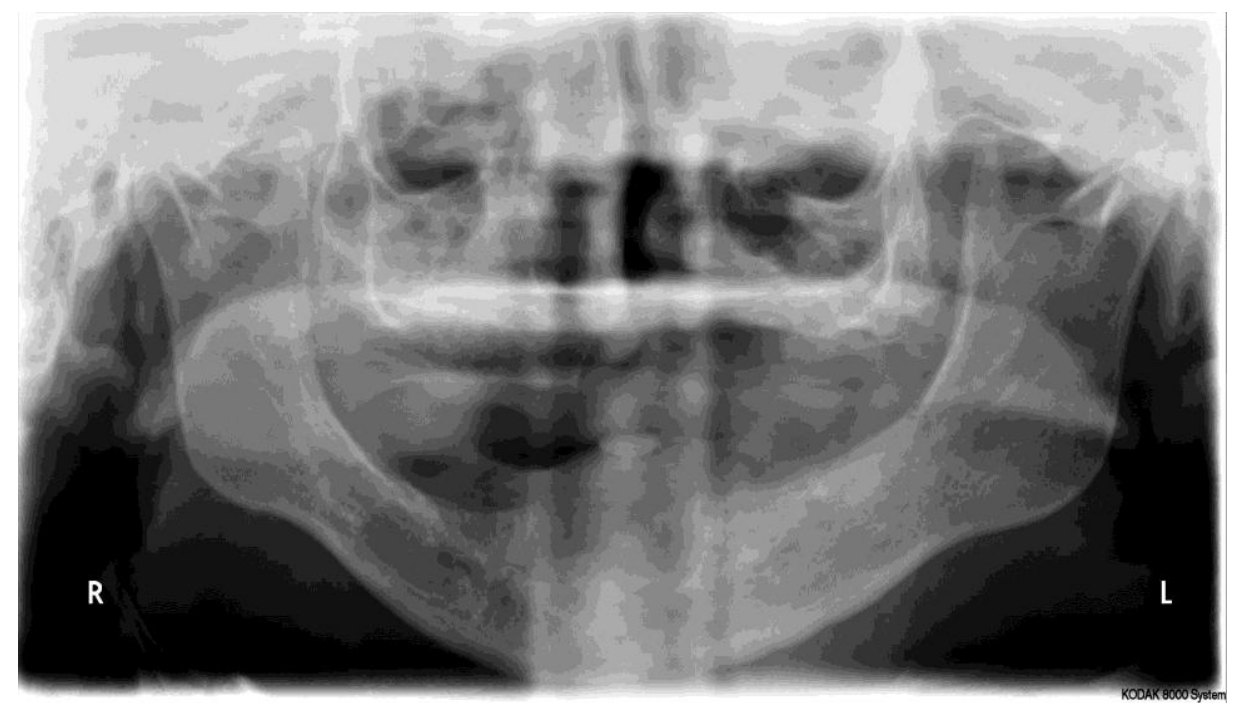

Figura 5.3 - Radiografia Panorâmica demostrando lesão óssea em Maxila e Mandíbula na região anterior 

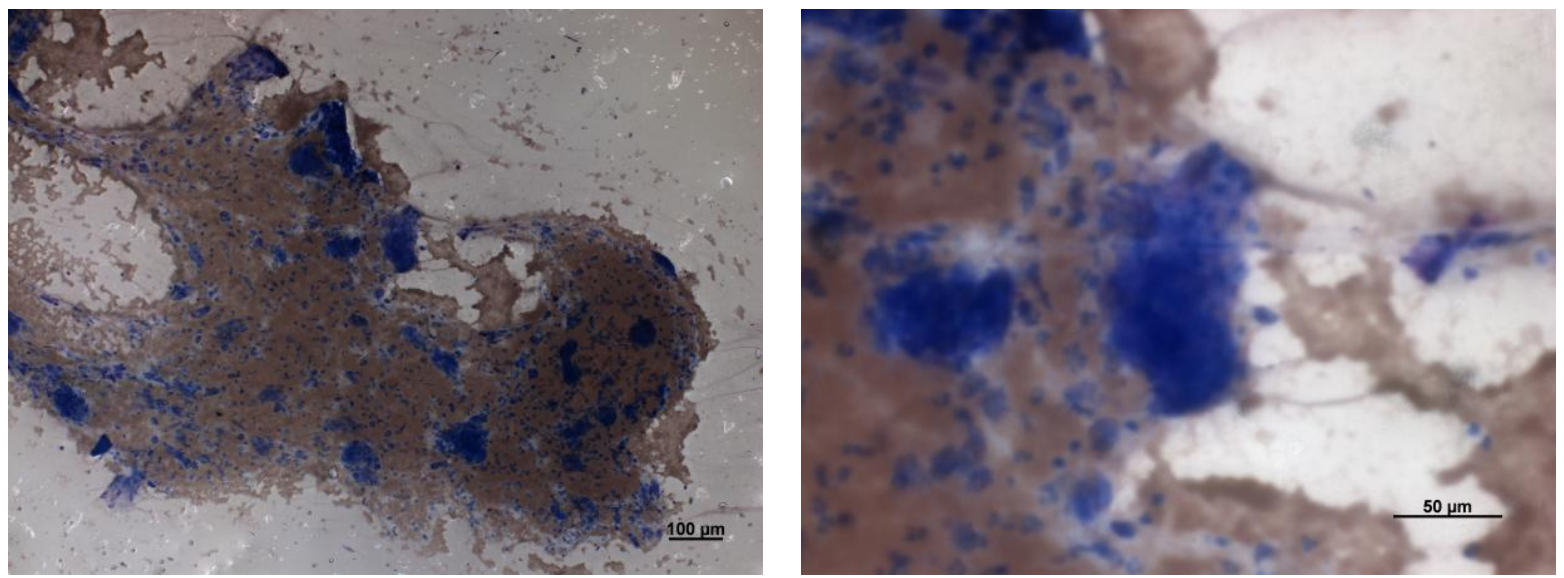

Fotomicrografia 5.5 - Presença de células gigantes no esfregaço, em menor e maior aumento, com laudo sugestivo de Lesão Central de Células Gigantes, em coloração de Panótico
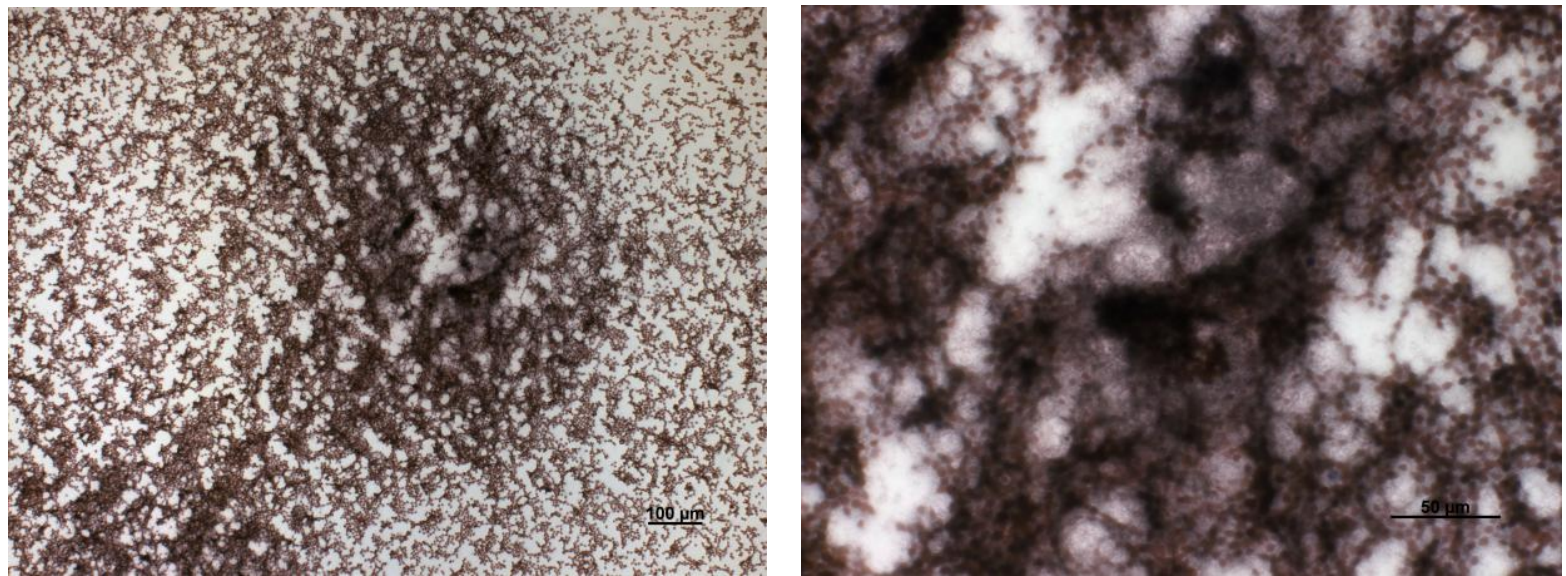

Fotomicrografia 5.6 - Presença de células gigantes no esfregaço, em menor e maior aumento, com laudo sugestivo de Lesão Central de Células Gigantes, em coloração de Papanicolau
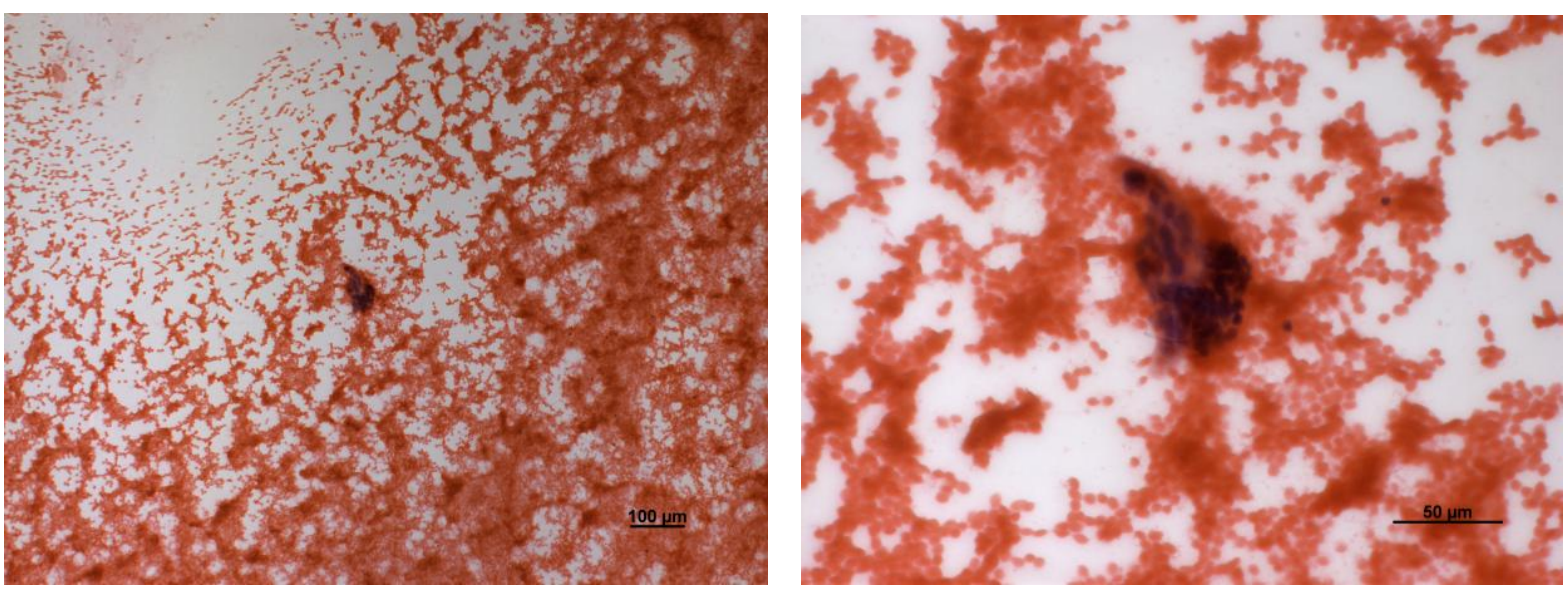

Fotomicrografia 5.7 - Presença de células gigantes no esfregaço, em menor e maior aumento, com laudo sugestivo de Lesão Central de Células Gigantes, em coloração de Hematoxilina-Eosina 
- Caso 3 - Paciente com suspeita clínica de Cisto do Ducto Nasopalatino
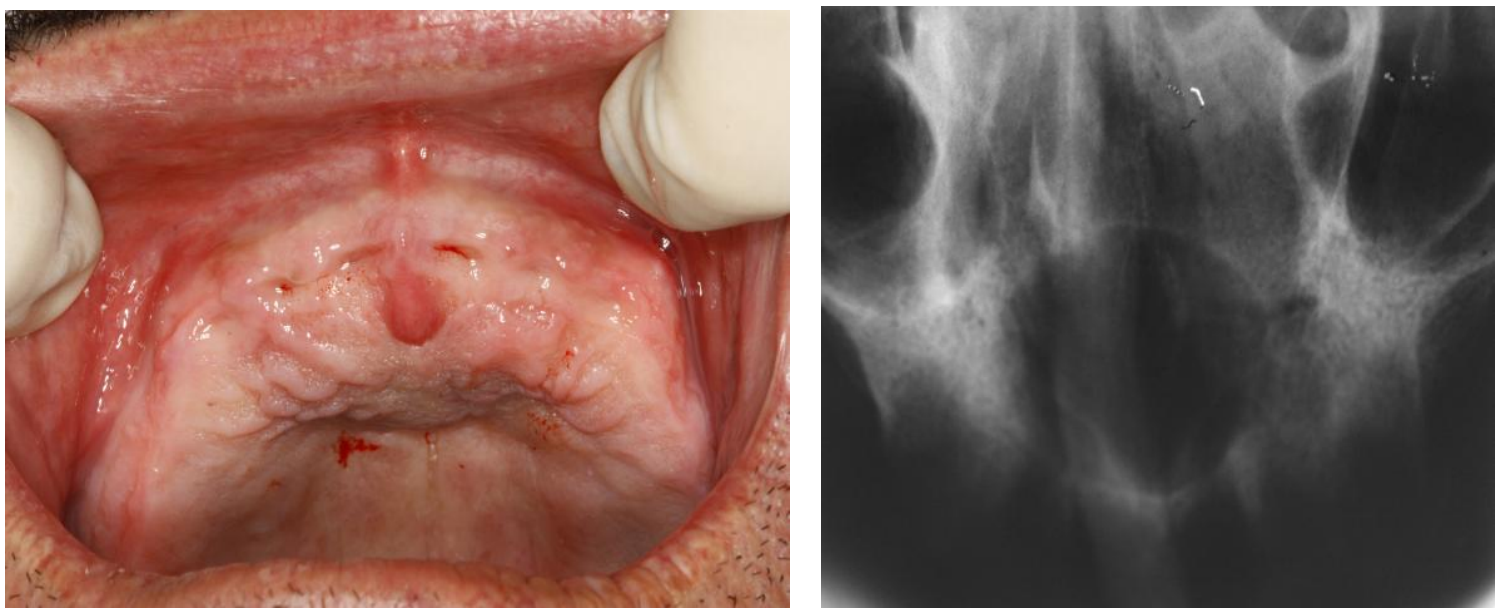

Figura 5.4 - Aspecto intra-oral de lesão nodular em maxila e radiografia oclusal demostrando lesão óssea em região de palato duro, com hipótese diagnóstica de cisto do ducto do nasopalatino
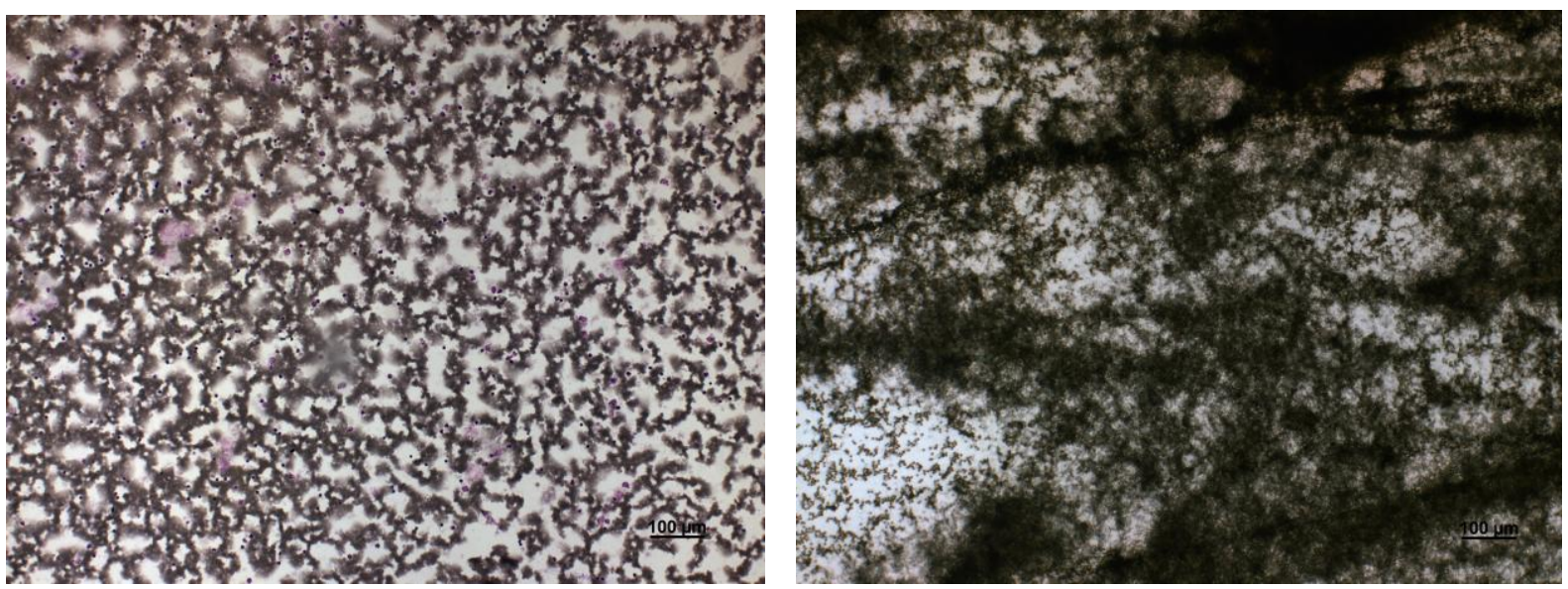

Fotomicrografia 5.8 - Presença de coagulo amorfo nos esfregaços das lâminas coradas com Panótico e Papanicolau, com laudo sugestivo de conteúdo cístico

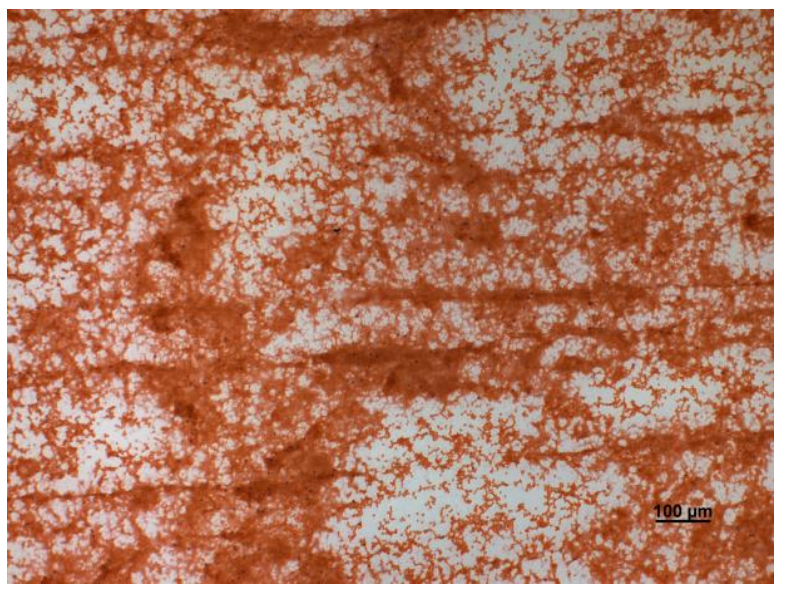

Fotomicrografia 5.9 - Presença de coagulo amorfo nos esfregaços de lâmina corada com Hematoxilina-Eosina, com laudo sugestivo de conteúdo cístico 
- Caso 4 - Paciente com suspeita clínica de neoplasia maligna

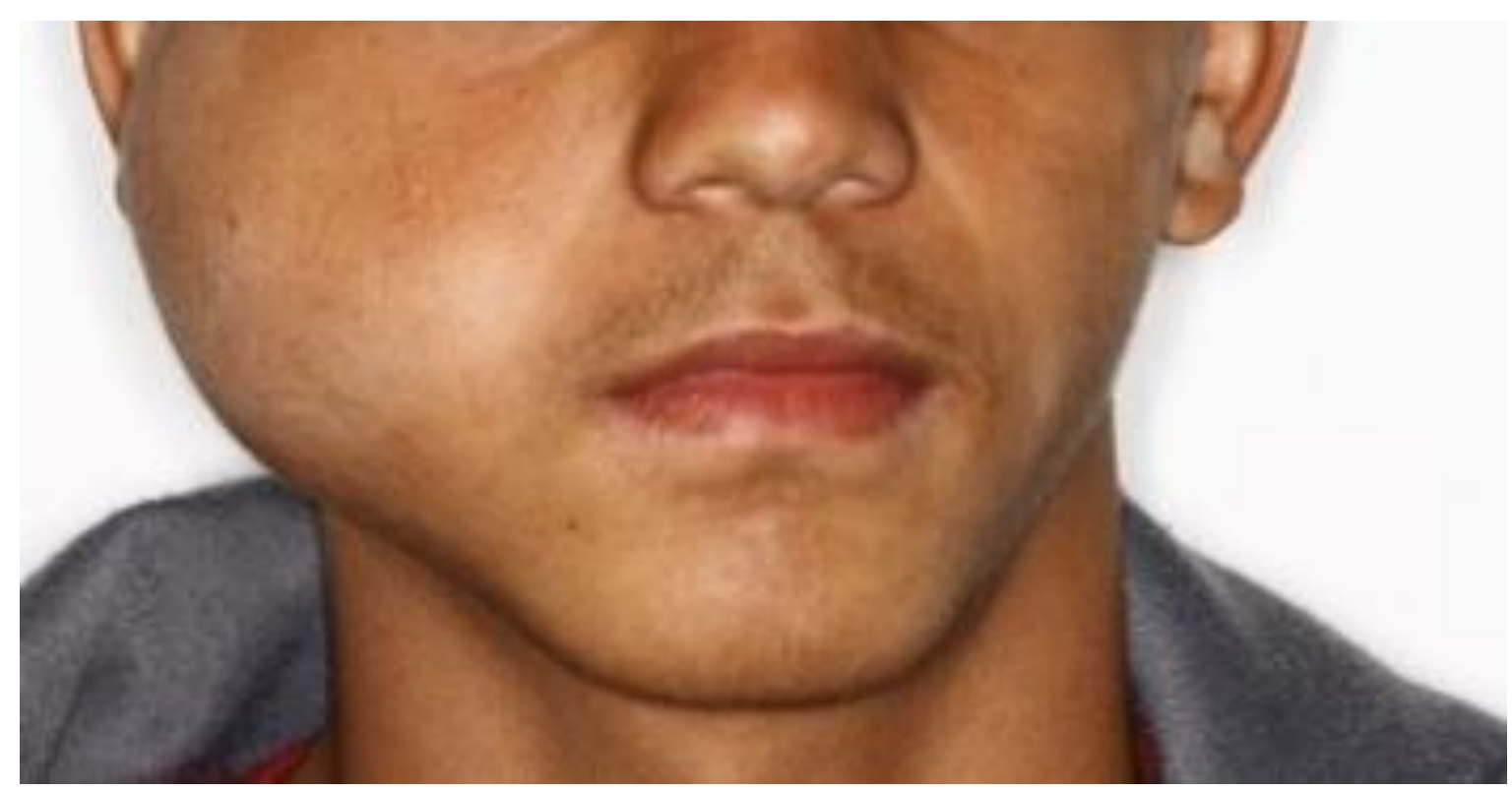

Figura 5.5 - Aspecto extra-oral de lesão nodular em região de mandíbula direita, com hipótese diagnóstica de neoplasia maligna

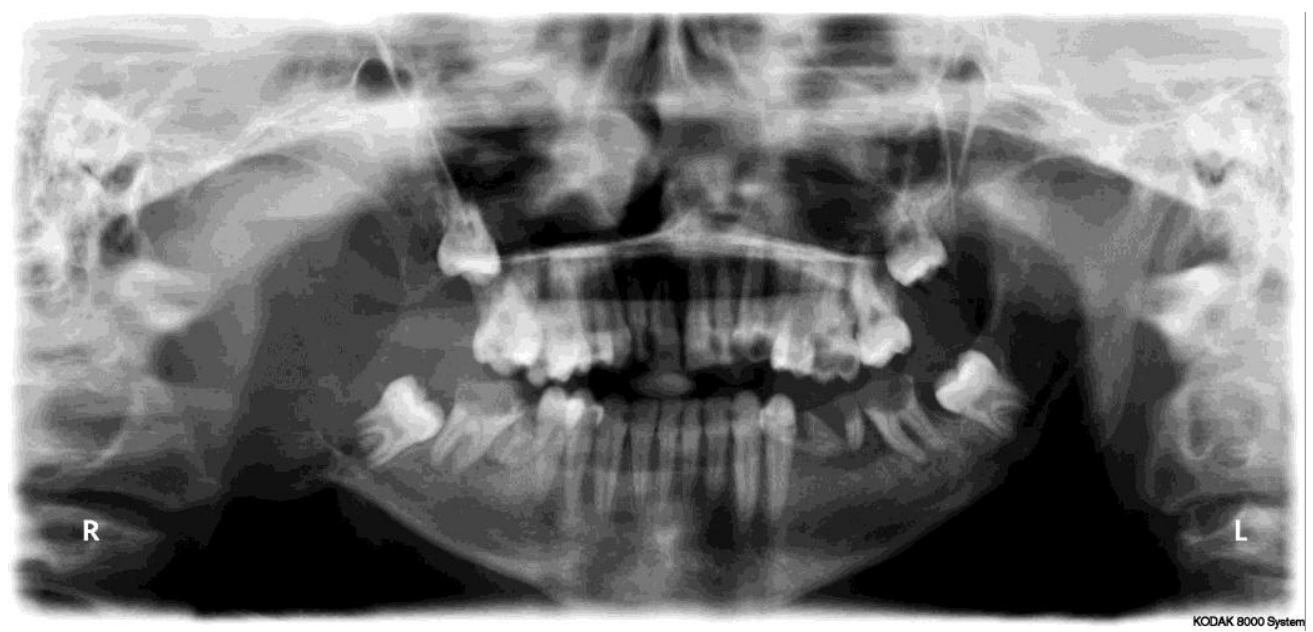

Figura 5.6- Radiografia Panorâmica demonstrando lesão óssea destrutiva em corpo e ramo da mandíbula 

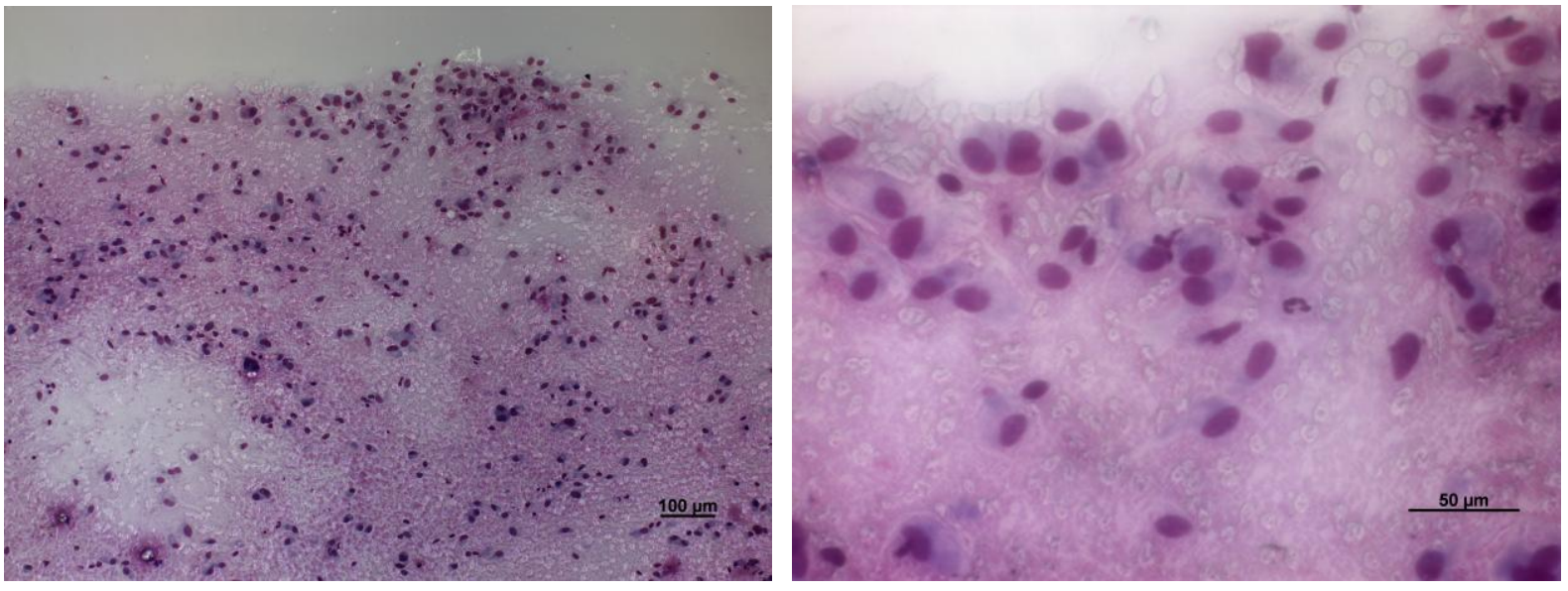

Fotomicrografia 5.10 - Presença de células multinucleadas atípicas no esfregaço, em menor e maior aumento, com laudo sugestivo de neoplasia mesenquimal maligna, em coloração de Panótico
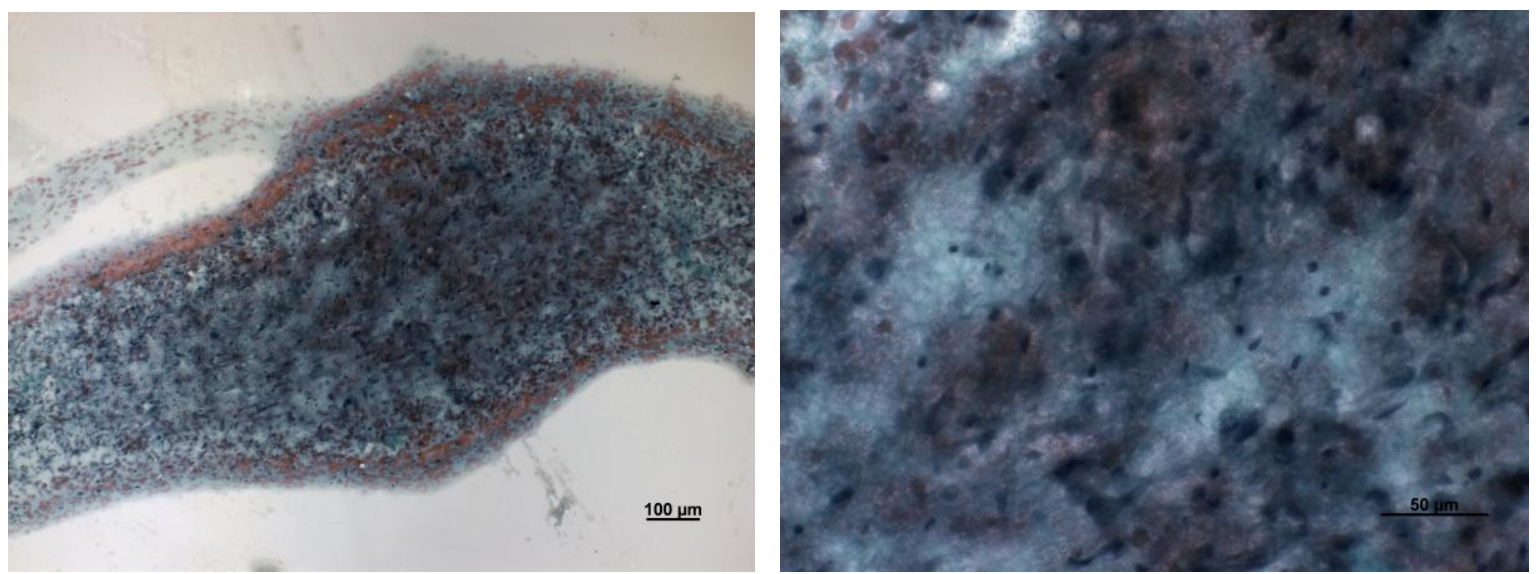

Fotomicrografia 5.11 - Presença de células multinucleadas atípicas no esfregaço, em menor e maior aumento, com laudo sugestivo de neoplasia mesenquimal maligna, em coloração de Papanicolau
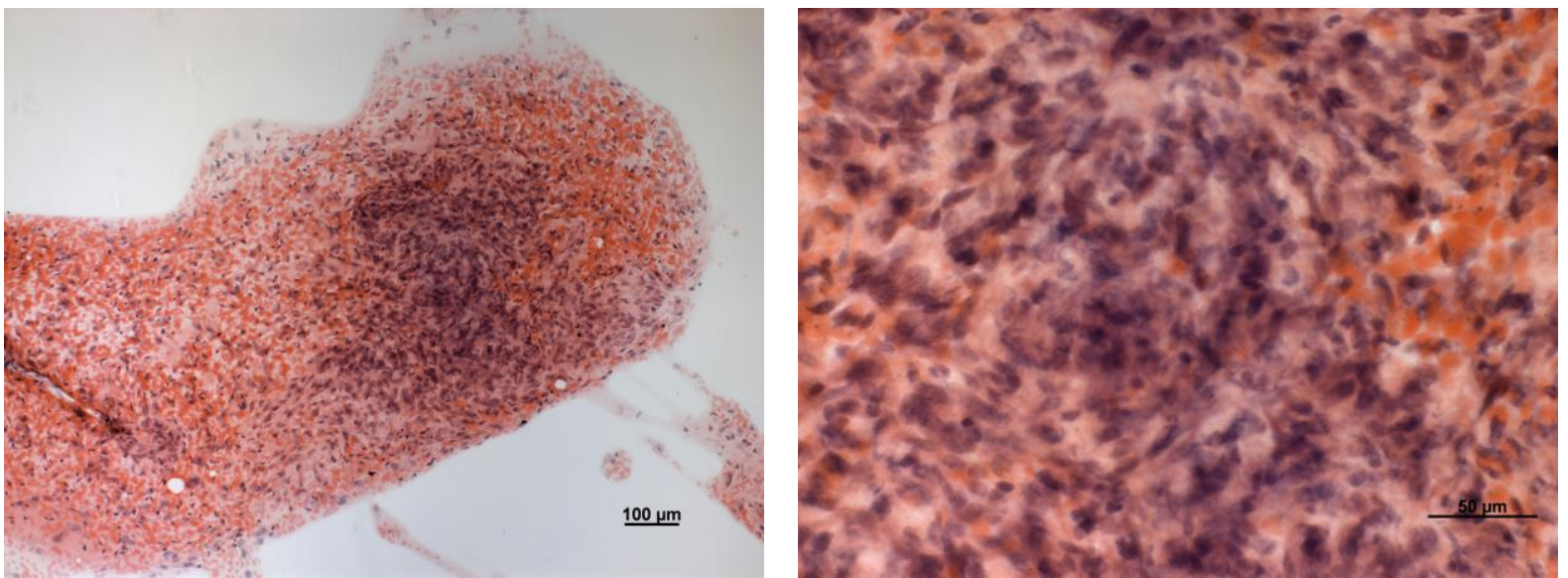

Fotomicrografia 5.12 - Presença de células multinucleadas atípicas no esfregaço, em menor e maior aumento, com laudo sugestivo de neoplasia mesenquimal maligna, em coloração de HematoxilinaEosina 
Tabela 5.13 - Descrição de local da lesão e resultados do Panótico, HE, Papanicolau e Anátomo Patológico

\begin{tabular}{|c|c|c|c|c|}
\hline Local & Panótico & HE & Papanicolaou & Resultado AP \\
\hline palato duro esquerdo & sugestivo de adenoma pleomórfico & adenoma pleomórfico & adenoma pleomórfico & Adenoma Pleomórfico \\
\hline mandibula lado direito & Processo inflamatório & sem material & exsudato hemorrágico & Tecido rico em miofibroblastos - inconclusivo \\
\hline palato duro & sem material & sem material & sem material & $\begin{array}{l}\text { Tumor odontogênico cístico calcificante } \\
\text { periférico }\end{array}$ \\
\hline mandibula lado direito & & sem material & sem material & Tumor odontogênico queratocístico \\
\hline mandíbula & conteúdo cístico & conteúdo cístico & conteúdo cístico & Cisto ósseo simples \\
\hline parótida direita & sugestivo de adenoma pleomórfico & sugestivo de adenoma pleomórfico & sugestivo de adenoma pleomórfico & tumor benigno - adenoma pleomórfico \\
\hline parótida e ramo de mandíbula $\mathrm{D}$ & neoplasia maligna mesenquimal & neoplasia maligna mesenquimal & neoplasia maligna mesenquimal & osteossarcoma \\
\hline maxila lado direito & Inconclusivo & conteúdo cistico & Inconclusivo & Tumor odontogênico cístico calcificante \\
\hline maxila direita & Inconclusivo & carcinoma mucoepidermóide & tumor glandular maligno & carcinoma mucoepidermóide \\
\hline mandibula lado esquerdo & & conteúdo cistico & conteúdo cistico & Cisto dentígero \\
\hline região retromolar direita & maligno (células intermediárias) & sugestivo de carcinoma mucoepidermóide & $\begin{array}{l}\text { sugestivo de carcinoma } \\
\text { mucoepidermóide }\end{array}$ & carcinoma mucoepidermóide \\
\hline região mentual & Inconclusivo & exsudato hemorrágico & exsudato hemorragico & Processo inflamatório crônico inespecífico \\
\hline região anterior de mandíbula & exudato hemorrágico & exsudato hemorrágico & exsudato hemorragico & Cisto radicular \\
\hline mandibula direita & sugestivo de conteúdo cístico & sugestivo de conteúdo cístico & sugestivo de conteúdo cístico & Cisto ósseo traumático \\
\hline maxila & sem material & sem material & presença de muco & Tumor odontogênico queratocístico \\
\hline mandibula direita & & conteúdo cístico & conteúdo cístico & Tumor odontogênico cístico calcificante \\
\hline mandibula lado esquerdo & Inconclusivo & inconclusivo & sugestivo de LCCG & LCCG \\
\hline ramo mandibular esquerdo & Inconclusivo & conteúdo cístico infectado & conteúdo cístico infectado & ameloblastoma \\
\hline maxila & abscesso & abscesso & abscesso & Processo inflamatório crônico e agudo \\
\hline ramo mandibular esquerdo & & Compatível com conteúdo cístico & Compatível com conteúdo cístico & ameloblastoma \\
\hline região submandibular & abscesso & abscesso & abscesso & provável cisto associado a lesão cutânea \\
\hline palato duro & sem material & Compatível com conteúdo cístico & Compatível com conteúdo cístico & Cisto radicular \\
\hline parotida direita & exsudato hemorrágico & exsudato hemorrágico & exsudato hemorrágico & tumor benigno \\
\hline mandibula lado direito & Inconclusivo & conteúdo cístico & tumor odontogênico queratocístico & cisto odontogênico \\
\hline palato duro/mole lado esquerdo & Inconclusivo & inconclusivo & $\begin{array}{l}\text { sugestivo de carcinoma } \\
\text { mucoepidermóide }\end{array}$ & carcinoma mucoepidermóide \\
\hline mandibula lado direito & Inconclusivo & $\begin{array}{l}\text { população de células pleomórficas } \\
\text { sugestiva de lesão maligna }\end{array}$ & Inconclusivo & Osteosarcoma \\
\hline maxila e mandíbula anterior & sugestivo de LCCG & sugestivo de LCCG & sugestivo de LCCG & LCCG \\
\hline palato duro & conteúdo cístico infectado & conteúdo cístico infectado & conteúdo cístico infectado & Cisto do ducto nasopalatino \\
\hline mandibula lado esquerdo & conteúdo cístico infectado & conteúdo cistico & conteúdo cistico & Tumor odontogênico queratocístico \\
\hline mandíbula lado direito & conteúdo cistico & conteúdo cistico & conteúdo cistico & Cisto radicular \\
\hline mucosa jugal esquerda & & conteúdo cístico dermóide & conteúdo cístico dermóide & cisto epidermóide \\
\hline palato duro & sugestivo de conteúdo cístico & sugestivo de conteúdo cístico & sugestivo de conteúdo cístico & Cisto do ducto nasopalatino \\
\hline região submentoniana & processo inflamtório & processo inflamtório & processo inflamtório & provável cisto braquial \\
\hline trígono retromolar & Inconclusivo & exsudato hemorrágico e inflamação & Inconclusivo & carcinoma epidermóide \\
\hline palato duro & adenoma pleomórfico & sem material & sem material & Processo inflamatório crônico inespecífico \\
\hline palato duro & $\begin{array}{c}\text { Abscesso com presença de } \\
\text { bactérias }\end{array}$ & abscesso com epitélio & $\begin{array}{c}\text { abscesso com presença de } \\
\text { bactérias }\end{array}$ & Cisto de natureza Indeterminada \\
\hline
\end{tabular}


Tabela 5.13 - Descrição de local da lesão e resultados do Panótico, HE, Papanicolau e Anátomo Patológico (Conclusão)

\begin{tabular}{|c|c|c|c|c|}
\hline Local & Panótico & HE & Papanicolau & Resultado AP \\
\hline borda lateral de língua esquerda & Inconclusivo & $\begin{array}{l}\text { neoplasia epitelial maligna } \\
\text { (adenocarcinoma) }\end{array}$ & $\begin{array}{l}\text { neoplasia epitelial maligna } \\
\text { (adenocarcinoma) }\end{array}$ & carcinoma epidermóide \\
\hline maxila anterior & conteúdo cístico infectado & conteúdo cístico infectado & conteúdo cístico infectado & Cisto Odontogênico \\
\hline parótida direita & $\begin{array}{l}\text { Processo inflamatório crônico } \\
\text { inespecífico }\end{array}$ & $\begin{array}{l}\text { Processo inflamatório crônico } \\
\text { inespecífico }\end{array}$ & $\begin{array}{l}\text { Processo inflamatório crônico } \\
\text { inespecífico }\end{array}$ & Sindrome de Sjögren \\
\hline maxila esquerda & conteúdo cistico & conteúdo cistico & conteúdo cistico & $\begin{array}{l}\text { Tumor odontogênico cístico } \\
\text { calcificante }\end{array}$ \\
\hline mucosa jugal direita & & sugestivo de mucocele & sugestivo de mucocele & mucocele e sialodenite crônica \\
\hline palato duro/mole & & sugetivo de carcinoma de seio maxilar & $\begin{array}{l}\text { sugestivo de carcinoma de seio } \\
\text { maxilar }\end{array}$ & $\begin{array}{l}\text { carcinoma epidermóide (de origem } \\
\text { sinusal) }\end{array}$ \\
\hline região anterior de maxila & Inconclusivo & conteúdo cístico infectado & conteúdo cístico infectado & Cisto radicular \\
\hline mandibula lado direito & conteúdo cístico infectado & conteúdo cístico infectado & conteúdo cístico infectado & Cisto odontogênico infectado \\
\hline assoalho bucal & sem material & sem material & exsudato hemorrágico & $\begin{array}{l}\text { Fragmento de mucosa e } \\
\text { submucosa }\end{array}$ \\
\hline
\end{tabular}




\section{DISCUSSÃO}

A coloração histológica é uma técnica que facilita o estudo microscópico de um tecido por meio da diferenciação de cor do mesmo (Tolosa, 2003). As colorações mais utilizadas na Punção Aspirativa por Agulha Fina (PAAF) são o as colorações tipo Romanowsky (Panótico - coloração de rápida visualização), o Papanicolau e a Hematoxilina-Eosina, sendo essa última a menos utilizada nessa técnica (Kline, 1988; Koss, 1979b; Koss, 1992; Ansari; Derias 1997).

No presente estudo, as colorações utilizadas foram as colorações de Panótico, Papanicolau e Hematoxilina-Eosina, com o objetivo de comparar quais delas demonstravam a melhor sensibilidade, especificidade e acurácia. Na maioria dos estudos, as três técnicas, ou duas, uma seca ao ar e as outras fixadas por álcool, são complementares para dar diagnóstico, sem diferenciar cada coloração (Schelkun; Grundy, 1991; Barnard et al., 1993; Castelli et al., 1993; Domanski; Akerman, 1998; August et al., 1999; Stone et al., 1998; Blocklage et al., 1997; Shah et al., 1999; Choudhury et al., 2000; Saran et al., 2000; Kumar et al., 2002; Tsamis et al., 2002; Vargas et al., 2007; Ashraf et al., 2010; Netto et al., 2008; Saleh et al., 2008; Fitzhugh et al., 2009; Gupta et al., 2009; Dereci et al., 2011; Santos et al., 2011; Fonseca et al., 2013; Kaliamoorthy et al., 2013; Cozzolino et al., 2014).

O procedimento foi realizado de acordo com a técnica descrita por Zadjicek (Kline, 1988; Fulciniti et al., 1997, Santos et al., 2011). O material era coletado mais de uma vez quando de lesões sólidas e somente de uma vez, quando o conteúdo líquido era presente. Grandes conteúdos hemorrágicos ou purulentos foram desprezados, a fim de se obter uma melhor visualização das amostras. Todos os pacientes que se enquadraram nos critérios de inclusão, passaram pelo procedimento de biópsia, com posterior laudo anátomo patológico a fim de se comparar os diagnósticos relatados nas duas técnicas. Todos os pacientes foram encaminhados a tratamento, após a emissão do laudo anátomo patológico.

A PAAF foi realizada em ambiente ambulatorial, por um clínico somente, sob anestesia local ou não. Não houve restrições de comorbidades, nem complicações trans operatórias ou pós operatórias. No nosso estudo, coletamos material proveniente de lesões de 8 pacientes abaixo dos 18 anos, demonstrando que é uma 
boa ferramenta em pacientes pediátricos, como relatado na literatura (Amedee; Dhurandhar, 2001).

O material foi então depositado em 6 lâminas, onde 2 lâminas foram secas ao ar e coradas pela técnica de Panótico e 4 lâminas foram fixadas em álcool para serem coradas pela técnica de Papanicolau e Hematoxilina-Eosina. As lâminas de Panótico foram coradas pelo mesmo clínico que coletou as amostras de PAAF.

Não houve uso de técnicas auxiliares ou de colorações especiais para se chegar ao diagnóstico, nem testes microbiológicos nos casos de coleta de material purulento.

O tempo de coloração empregado na técnica de coloração por Panótico é rápido, geralmente de 1 minuto de acordo com o fabricante, sendo fácil de ser realizada e de ser visualizada em microscópio (Platt et al., 1990). No presente estudo, não havia um patologista no momento da coleta, o que dificultou com que fosse visualizado se o material coletado era suficiente para análise ou não.

Isso reflete em nossa taxa de inconclusivos e sem material coletado em cada técnica de coloração. Na técnica de coloração por Panótico, 18 casos foram inconclusivos. Destes casos inconclusivos, 5 eram de lesões malignas, 8 de lesões benignas e 5 casos não possuíam material suficiente para a análise, prováveis erros de técnica na coleta da PAAF. Assim, como nos 11 casos inconclusivos da técnica de coloração por Papanicolau onde 2 eram de lesões malignas, 7 eram de lesões benignas e 2 casos não possuíam material suficiente para a análise e nos 11 casos inconclusivos da técnica de coloração por Hematoxilina-Eosina onde 2 casos eram de lesões malignas, 4 casos eram de lesões benignas e 5 casos não possuíam material suficiente para a análise.

Muitos trabalhos enfatizam a presença de um patologista na hora da coleta ou um citotecnólogo (capaz de coletar e visualizar a amostra no mesmo momento), demonstrando que esses profissionais são essenciais para que a acurácia da técnica chegue a níveis elevados, tornando-a confiável para uso diagnóstico, auxiliando na diminuição entre o diagnóstico e o tratamento da lesão (Cohen et al., 2004; Gomez-Macías et al., 2009; Santos et al., 2011; Jeong et al., 2013; Reddy et al., 2013).

Não houve falsos-positivos ou falsos-negativos na análise realizada, como demonstram alguns casos presentes na literatura (Robaina et al., 2007; Saleh et al., 
2008). Apesar de ser algo positivo frente a análise realizada, nos dificultou nos cálculos de sensibilidade e especificidade, pois não refletia a verdade relatada no estudo. Por esse motivo, para fins de estudo estatístico, os casos inconclusivos provenientes de lesões malignas foram considerados como falso-negativos e os casos inconclusivos provenientes de lesões benignas foram considerados falsopositivos.

Os cálculos de sensibilidade, especificidade e acurácia foram feitos segundo as definições de Trott (Florentine et al., 2006; Santos et al., 2011) onde a sensibilidade é a capacidade do teste de identificar lesões malignas e a especificidade é a capacidade do teste de identificar leões benignas. As lesões benignas consideradas foram as neoplasias benignas, as lesões proliferativas não neoplásicas, os processos inflamatórios e as lesões reacionais. A acurácia do teste foi calculada como a quantidade dos resultados da PAAF semelhantes aos resultados do Anátomo Patológico.

Como descrito anteriormente por Santos (2010), a acurácia foi calculada como a relação entre resultados da PAAF compatíveis aos do AP e os resultados da amostra total excluindo os casos inconclusivos. A sensibilidade foi calculada pela relação de verdadeiros malignos da PAAF e a soma entre os verdadeiros malignos e os falso-negativos da PAAF e a especificidade foi calculada pela relação de verdadeiros benignos da PAAF e a soma de verdadeiros benignos e os falsopositivos da PAAF, para cada técnica de coloração, a fim de nos demonstrar, na metodologia do presente estudo, qual possuía melhor sensibilidade, especificidade e acurácia.

$\mathrm{Na}$ coloração de Panótico, o cálculo da sensibilidade foi de 28,6\%, a especificidade foi de $76 \%$ e a acurácia do teste foi de $15,4 \%$. Na coloração de Papanicolau, o cálculo da sensibilidade foi de $71,4 \%$, a especificidade foi de $76,7 \%$ e a acurácia do teste foi de $23,3 \%$. Na coloração de Hematoxilina-Eosina, o cálculo da sensibilidade foi de $71,4 \%$, a especificidade foi de $82,1 \%$ e a acurácia do teste foi de $28,6 \%$.

Por esses dados, conseguimos inferir, pela metodologia do presente estudo que, na técnica de coloração por Papanicolau e Hematoxilina-Eosina a sensibilidade para diagnosticar lesões malignas foi igual, mas superior a coloração de Panótico. A especificidade para identificar lesões benignas foi maior na técnica de Hematoxilina- 
Eosina, que nas técnicas de Papanicolau e de Panótico e que a acurácia foi superior na técnica de coloração por Hematoxilina-Eosina, quando comparadas com as técnicas de coloração por Papanicolau e Panótico.

Anand et al. (2004), comparou as colorações usadas no imprint citológico de linfonodos sentinelas metastáticos em carcinoma de mama. Foram utilizadas as técnicas de colorações de Giemsa, Hematoxilina-Eosina e Papanicolau. No estudo, o relato é que essas três colorações devem ser usadas concomitantes a fim de dar diagnóstico final dessas lesões. A acurácia na técnica de coloração por Giemsa foi de $95,3 \%$, na técnica de coloração por Hematoxilina-Eosina foi de 90,6\% e na técnica de coloração por Papanicolau foi de $91,58 \%$. Houve uma maior taxa de falsos-positivos e negativos nas técnicas de coloração por Giemsa e Papanicolau, que pela técnica de coloração por Hematoxilina-Eosina. A técnica de coloração por Giemsa apresentou uma melhor acurácia, sensibilidade e especificidade, quando comparada as outras duas técnicas. Há o relato também, que as técnicas de coloração por Giemsa e Hematoxilina-Eosina, são as mais utilizadas nesse tipo de avaliação. Segundo o autor, a técnica de coloração por Papanicolau demonstra melhor a diferenciação escamosa e a queratinização das células. A presença de artefatos secos, se da mais nas técnicas onde as lâminas são fixadas em álcool. Sua conclusão é que a experiência do patologista em determinada técnica de coloração, demonstra nos resultados do trabalho.

Como em outros estudos (Ansari; Derias, 1997; Krafts; Pambuccian, 2011) , a técnica de coloração de Panótico, por ser feita com lâminas secas ao ar, demonstrou células de tamanhos maiores e sem background nas lâminas. Facilitando em alguns pontos a visualização celular, quando a amostra possuía material suficiente para a análise. Essa técnica também foi boa em demonstrar presença bacteriana nas amostras estudadas, como relatada em outros estudos (Santiago $\mathrm{K}$ et al., 2000; Krafts; Pambuccian, 2011).

Já as lâminas fixadas em álcool e coradas pela técnica de Papanicolau e Hematoxilina-Eosina, demonstraram uma maior preservação das células, com melhor preservação de sua morfologia, como num corte histológico, sendo a coloração de Hematoxilina-Eosina, segundo o patologista que avaliou as lâminas, a que preserva mais as características histológicas. 
A coloração que apresentou mais artefatos foi a coloração de Papanicolau, sendo a mais difícil de ser visualizada, devido ao padrão de cores que apresenta. Em lâminas de conteúdo cístico ou com muito conteúdo hemorrágico, as lâminas apresentam um aspecto granuloso, em tons de cor marrom, dificultando muito a visualização das células. Foi a coloração que mais apresentou artefatos na visualização das lâminas.

Lâminas de conteúdo cístico, nas três colorações apresentaram um coágulo amorfo, bem característico, como demonstrado nos exemplos acima, facilitando o seu diagnóstico. Já, nesses casos, não houve visualização de células presentes nas cápsulas, não sendo possível dar um diagnóstico preciso de cada lesão cística.

Gupta et al. (2009), ainda relata que lesões fibro-ósseas da cavidade oral são difíceis de dar diagnóstico, devido ao pouco material coletado na amostra, sendo a correlação entre o diagnóstico clínico e histológico imprescindível nesses casos.

As células epiteliais são de fácil visualização na técnica de coloração de Papanicolau, por sua estrutura corar em um tom verde, bem específico da técnica.

Ahmed et al. (2009), comparou a utilidade da citologia convencional em base líquida com as de esfregaço direto para lesões orais, nas técnicas de Papanicolau e de May-Grünhald-Giemsa. As lâminas de base líquida apresentaram qualidade de coloração melhores quando comparadas com as de esfregaço direto, tanto em Papanicolau quanto em May-Grünwald-Giemsa, mas as lâminas coradas por Papanicolau apresentaram qualidades ainda superiores.

Em nosso estudo, as lâminas coradas pelas técnicas de Panótico e de Hematoxilina-Eosina apresentaram uma qualidade de coloração superior quando comparadas com as lâminas coradas pela técnica de Papanicolau.

Há trabalhos ainda que enfatizam o uso de outras técnicas de colorações rápidas para dar diagnóstico, como o Ultra Fast Papanicolau ou Ultra Fast Papanicolau modificado (Yang; Waisman, 2006; Kamal et al., 2011; Choudhary et al., 2012) em PAAF.

Outros trabalhos enfatizam somente o uso das técnicas de coloração tipo Romanowsky para diagnóstico definitivo das lesões (Nagel et al., 1999; Postema et al., 2004; Wu et al., 2010; Sehgal et al., 2013; Yang et al., 2014) em PAAF, assim como os que enfatizam somente o uso das técnicas de coloração as quais as lâminas são fixadas por álcool (Stone et al., 1998). 
A técnica de PAAF apresentou alta acurácia em lesões de glândulas salivares, maiores e menores, tanto para lesões benignas, quanto para lesões malignas, nas três colorações, assim como as lesões inflamatórias.

Frente a esses pontos apresentados, devemos ter em mente que a PAAF é uma técnica simples e segura, não apresentando riscos ao paciente quando de sua realização ou no seu pós-operatório.

O treinamento da técnica, aliados a presença de um patologista no momento da coleta, ou mesmo um clínico treinado a avaliar o material coletado, diminuiria significativamente a amostra de inconclusivos, encorajando assim o uso da técnica de coloração por Panótico, para uma avaliação prévia do material coletado.

A PAAF é uma boa ferramenta pré-operatória, diminuindo então, o tempo entre o diagnóstico de uma determinada lesão e seu subsequente tratamento, mas devemos ter em mente as indicações e limitações que a técnica oferece.

Mesmo onde a utilização da PAAF é indicada, não devemos deixar de respeitar a propedêutica clinica, colhendo toda o histórico médico e odontológico, assim como os exames complementares que podemos utilizar, para a avaliação de um determinado paciente. Isso nos auxilia a um diagnóstico clinico diferencial, norteando então, o diagnóstico definitivo na PAAF.

Em situações onde a suspeita de uma lesão é de malignidade, frente a um diagnóstico benigno ou inconclusivo de PAAF, a biópsia deve ser realizada, já que é um padrão-ouro para o diagnóstico final e definitivo das lesões em geral.

A experiência do patologista ao ver as lâminas de PAAF é essencial para que seu diagnóstico seja o mais preciso, assim como a familiarização deste com uma determinada técnica de coloração, auxiliando portanto, consideravelmente no diagnóstico final do material coletado pela PAAF.

Mesmo sendo pouco utilizada nos trabalhos apresentados no presente estudo, a técnica de coloração de Hematoxilina-Eosina, deve ser considerada pelo patologista, no momento de visualizar as laminas de PAAF, por preservar a estrutura celular semelhante aos cortes histológicos.

Podemos encorajar também, para futuros trabalhos, o uso de técnicas auxiliares, para um refinamento diagnóstico, aumentando portanto a acurácia da técnica. 
Mesmo frente todas as limitações encontradas no presente estudo, o uso da PAAF em lesões de cavidade oral e região de cabeça e pescoço, nos limites legais da atuação odontológica, não deve ser desencorajado e novos trabalhos avaliando o quanto essa ferramenta diagnóstica é importante, guardadas as suas devidas indicações, devem ser realizados. 


\section{CONCLUSÃO}

Podemos concluir, pela metodologia do presente estudo, que :

- A coloração de Hematoxilina-Eosina e de Papanicolalou demonstraram a mesma sensibilidade, para diagnosticar neoplasias malignas.

- A coloração de Hematoxilina-Eosina demonstrou uma melhor especificidade para diagnosticar neoplasias benignas, quando comparadas com a coloração de Papanicolau e a coloração de Panótico.

- A coloração de Hematoxilina-Eosina demonstrou uma melhor acurácia, para dar diagnóstico definitivo, seguida da coloração de Papanicolau e da coloração de Panótico. 


\section{REFERÊNCIAS ${ }^{1}$}

Acree T, Abreo F, Smith BR, Bagby J, Heard JS. Diagnosis of dermoid cyst of the floor of the mouth by fine-needle aspiration cytology: a case report. Diagn Cytopathol. 1999 Feb;20(2):78-81.

Ahmed HG, Edris AM, Mohmed EA, Hussein MO. Value of centrifugated liquid-based cytology by Papanicolaou and May-Grünwald in oral epithelial cells. Rare Tumors. 2009;1(1):e12.

Amedee RG, Dhurandhar NR. Fine-needle aspiration biopsy. Laryngoscope. 2001 Sep;111(9):1551-7.

Anand A, Brockie ES. Cytomorphological features of salivary duct carcinoma ex pleomorphic adenoma: diagnosis by fine-needle aspiration biopsy with histologic correlation. Diagn Cytopathol. 1999 Jun;20(6):375-8.

Anand M, Kumar R, Jain P, Asthana S, Deo SV, Shukla NK, et al. Comparison of three different staining techniques for intraoperative assessment of nodal metastasis in breast cancer. Diagn Cytopathol. 2004 Dec;31(6):423-6.

Ansari NA, Derias NW. Fine needle aspiration cytology. J Clin Pathol. 1997 Jul;50(7):541-3.

Ashraf MJ, Azarpira N, Anbardar MH, Hashemi SB. Oncocytic lipoadenoma of the parotid gland: Cytological findings and differential diagnosis on fine-needle aspiration. Diagn Cytopathol. 2014 Mar. 3. doi:10.1002/dc.23135 [Epub ahead of print]

Ashraf MJ, Azarpira N, Nowroozizadeh B, Shishegar M, Khademi B, Faramarzi A, et al. Fine needle aspiration cytology of palatine tonsils: a study of 112 consecutive adult tonsillectomies. Cytopathology. 2010 Jun;21(3):170-5.

August M, Faquin WC, Ferraro NF, Kaban LB. Fine-needle aspiration biopsy of intraosseous jaw lesions. J Oral Maxillofac Surg. 1999 Nov;57(11):1282-6; discussion 7.

1 De acordo com o estilo Vancouver. 
Bagga P, Pandey P, Shahi M, Mittal A, Mehta V, Ganju A. Parotid gland tuberculosis diagnosed on FNAC: a case report. Cytopathology. 2010 Apr;21(2):127-9.

Bancroft JD. Theory and practice of histological technique. 4. ed. Edinburgh: Churchill Livingstone; 1996.

Barnard NA, Paterson AW, Irvine GH, Mackenzie ED, White H. Fine needle aspiration cytology in maxillofacial surgery--experience in a district general hospital. Br J Oral Maxillofac Surg. 1993 Aug;31(4):223-6.

Bezrukov AV. Romanowsky Staining: On the Question of Priority. pp. 1-11. Moscow: EMCO Ltd.; 2010.

Bocklage TJ, Ardeman T, Schaffner D. Ameloblastic fibroma: a fine-needle aspiration case report. Diagn Cytopathol. 1997 Oct;17(4):280-6.

Carrillo JF, Ramírez R, Flores L, Ramirez-Ortega MC, Arrecillas MD, Ibarra M, et al. Diagnostic accuracy of fine needle aspiration biopsy in preoperative diagnosis of patients with parotid gland masses. J Surg Oncol. 2009 Aug;100(2):133-8.

Castelli M, Gattuso P, Reyes C, Solans EP. Fine needle aspiration biopsy of intraoral and pharyngeal lesions. Acta Cytol. 1993 Jul-Aug;37(4):448-50.

Cha I, Long SR, Ljung BM, Miller TR. Low-grade lymphoma of mucosa-associated tissue in the parotid gland: a case report of fine-needle aspiration cytology diagnosis using flow cytometric immunophenotyping. Diagn Cytopathol. 1997 Apr;16(4):345-9.

Choudhary P, Sudhamani S, Pandit A, Kiri V. Comparison of modified ultrafast Papanicolaou stain with the standard rapid Papanicolaou stain in cytology of various organs. J Cytol. 2012 Oct;29(4):241-5.

Choudhury M, Dhar S, Bajaj P. Primary diagnosis of ameloblastoma by fine-needle aspiration: a report of two cases. Diagn Cytopathol. 2000 Dec;23(6):414-6.

Clark G, Kasten FH. History of staining. 3rd ed. Baltimore: Williams \& Wilkins; c1983.

Cohen EG, Patel SG, Lin O, Boyle JO, Kraus DH, Singh B, et al. Fine-needle aspiration biopsy of salivary gland lesions in a selected patient population. Arch Otolaryngol Head Neck Surg. 2004 Jun;130(6):773-8. 
Costas A, Castro P, Martín-Granizo R, Monje F, Marrón C, Amigo A. Fine needle aspiration biopsy (FNAB) for lesions of the salivary glands. Br J Oral Maxillofac Surg. 2000 Oct;38(5):539-42.

Cozzolino I, Vigliar E, Todaro P, Peluso AL, Picardi M, Sosa Fernandez LV, et al. Fine needle aspiration cytology of lymphoproliferative lesions of the oral cavity. Cytopathology. 2014 Feb. doi: 10.1111/cyt.12132. [Epub ahead of print]

Dereci O, Oztürk A, Günhan O. The efficacy of fine needle aspiration cytology in the preoperative evaluation of parakeratotic odontogenic keratocysts. Acta Cytol. 2011;55(2):131-4.

Domanski HA, Akerman M. Fine-needle aspiration cytology of tongue swellings: a study of 75 cases. Diagn Cytopathol. 1998 Jun;18(6):387-92.

Ersöz C, Cetik F, Aydin O, Cosar EF, Talas DU. Salivary duct carcinoma ex pleomorphic adenoma: analysis of the findings in fine-needle aspiration cytology and histology. Diagn Cytopathol. 1998 Sep;19(3):201-4.

Fitzhugh VA, Maniar KP, Gurudutt VV, Rivera M, Chen H, Wu M. Fine-needle aspiration biopsy of granular cell tumor of the tongue: a technique for the aspiration of oral lesions. Diagn Cytopathol. 2009 Nov;37(11):839-42.

Fitzhugh VA, McCash SI, Park E, Wiesenthal C, LaBombardi V, Chen H. Mycobacterium avium complex infection in a neck abscess: a diagnostic pitfall in fineneedle aspiration biopsy of head and neck lesions. Diagn Cytopathol. 2009 Jul;37(7):527-30.

Florentine BD, Staymates B, Rabadi M, Barstis J, Black A, Hospital CCotHMNM. The reliability of fine-needle aspiration biopsy as the initial diagnostic procedure for palpable masses: a 4-year experience of 730 patients from a community hospitalbased outpatient aspiration biopsy clinic. Cancer. $2006 \mathrm{Jul}$;107(2):406-16.

Fonseca FP, Ribeiro AC, Santos-Silva AR, Vargas PA, Lopes MA. Fine needle aspiration cytology and intralesional steroid injection in a central giant cell granuloma affecting the gingiva: a new clinical approach. Braz Dent J. 2013;24(4):420-7.

Fulciniti F, Califano L, Zupi A, Vetrani A. Accuracy of fine needle aspiration biopsy in head and neck tumors. J Oral Maxillofac Surg. 1997 Oct;55(10):1094-7.

Gomez-Macías GS, Garza-Guajardo R, Segura-Luna J, Barboza-Quintana O. Inadequate fine needle aspiration biopsy samples: pathologists versus other specialists. Cytojournal. 2009;6:9. 
Gray, W. Diagnostic cytopathology. Edinburgh: Churchill Livingstone; 1995.

Gupta N, Gupta R, Bakshi J, Rajwanshi A. Fine needle aspiration cytology in a case of fibrous dysplasia of jaw. Diagn Cytopathol. 2009 Dec;37(12):920-2.

Horobin RW, Walter KJ. Understanding Romanowsky staining. I: The RomanowskyGiemsa effect in blood smears. Histochemistry. 1987;86(3):331-6.

Jeong WJ, Park SJ, Cha W, Sung MW, Kim KH, Ahn SH. Fine needle aspiration of parotid tumors: diagnostic utility from a clinical perspective. J Oral Maxillofac Surg. 2013 Jul;71(7):1278-82.

Jörundsson E, Lumsden JH, Jacobs RM. Rapid staining techniques in cytopathology: a review and comparison of modified protocols for hematoxylin and eosin, Papanicolaou and Romanowsky stains. Vet Clin Pathol. 1999;28(3):100-8.

Kaliamoorthy S, Venkatapathy R, Babu P, Veeran V. Practical significance of utilizing fine needle aspiration cytology as an adjunct diagnostic aid in the preoperative presumptive diagnosis of ameloblastoma. J Cytol. 2013 Oct;30(4):247-51.

Kalogeraki A, Korkolopoulou P, Tamiolakis D, Papadakis CE, C Sepsa C, Lagoudaki E, et al. Myoepithelial carcinoma of the parotid gland. Malays J Pathol. 2014 Apr;36(1):51-4.

Kamal MM, Kulkarni MM, Wahane RN. Ultrafast papanicolaou stain modified for developing countries: efficacy and pitfalls. Acta Cytol. 2011;55(2):205-12.

Kline TS. Handbook of fine needle aspiration biopsy cytology. 2nd. New York: Churchill Livingstone; 1998.

Keebler CM, Somrak TM. The Manual of cytotechnology. 7th ed. Chicago: ASCP Press; 1993.

Koss, LG. Diagnostic cytology and its histopathologic bases. 3d ed. Philadelphia: Lippincott; 1979a.v1.

Koss, LG. Diagnostic cytology and its histopathologic bases. 3d ed. Philadelphia: Lippincott; 1979b. v2.

Koss LG. Diagnostic cytology and its histopathologic bases. 4th ed. Philadelphia: Lippincott; 1992. 
Krafts KP, Pambuccian SE. Romanowsky staining in cytopathology: history, advantages and limitations. Biotech Histochem. 2011 Apr;86(2):82-93.

Krishnamurthy S. Applications of molecular techniques to fine-needle aspiration biopsy. Cancer. 2007 Apr;111(2):106-22.

Kumar N, Jain S, Gupta S. Maxillary odontogenic myxoma: a diagnostic pitfall on aspiration cytology. Diagn Cytopathol. 2002 Aug;27(2):111-4.

Lever JV, Trott PA, Webb AJ. Fine needle aspiration cytology. J Clin Pathol. 1985 Jan;38(1):1-11.

Loong TW. Understanding sensitivity and specificity with the right side of the brain. BMJ. 2003 Sep;327(7417):716-9.

Mighell AJ, High AS. Histological identification of carcinoma in 21 gauge needle tracks after fine needle aspiration biopsy of head and neck carcinoma. J Clin Pathol. 1998 Mar;51(3):241-3.

Millar AJ, Sinclair-Smith C, Rode H, Hartley P, Karabus C, Cywes S. Fine-needle cytology of solid tumors: method, diagnostic accuracy, and role in management. J Pediatr Surg. 1990 Oct;25(10):1088-91.

Moatamed NA, Naini BV, Fathizadeh P, Estrella J, Apple SK. A correlation study of diagnostic fine-needle aspiration with histologic diagnosis in cystic neck lesions. Diagn Cytopathol. 2009 Oct;37(10):720-6.

Nagel H, Hotze HJ, Laskawi R, Chilla R, Droese M. Cytologic diagnosis of adenoid cystic carcinoma of salivary glands. Diagn Cytopathol. 1999 Jun;20(6):358-66.

Netto JdeN, Miranda AM, da Silveira HM, dos Santos TC, Pires FR. Fine-needle aspiration biopsy as an auxiliary diagnostic tool on intraoral minor salivary gland adenoid cystic carcinoma. Oral Surg Oral Med Oral Pathol Oral Radiol Endod. 2008 Aug;106(2):242-5.

Pisharodi LR. False-negative diagnosis in fine-needle aspirations of squamous-cell carcinoma of head and neck. Diagn Cytopathol. 1997 Jul;17(1):70-3.

Platt JC, Davidson D, Nelson CL, Weisberger E. Fine-needle aspiration biopsy: an analysis of 89 head and neck cases. J Oral Maxillofac Surg. 1990 Jul;48(7):702-6; discussion 6-7. 
Postema RJ, van Velthuysen ML, van den Brekel MW, Balm AJ, Peterse JL. Accuracy of fine-needle aspiration cytology of salivary gland lesions in the netherlands cancer institute. Head Neck. 2004 May;26(5):418-24.

Ramzy I. Clinical cytopathology \& aspiration biopsy : fundamental principles and practice. 1d ed. Norwalk, Conn.: Appleton \& Lange; 1990.

Reddy VM, Bennett WO, Bassett E, Cunliffe DJ, Fryer LC, Reece PH, et al. On-site cytotechnician evaluation of the adequacy of fine needle aspiration in a neck lump clinic. Ann R Coll Surg Engl. 2013 Nov;95(8):595-8.

Robaina TC, Coutinho ACA; Valladares, CP; Dias, EP; Lourenço; SQC. Correlationship of citopathology and histopathology on oral mucosa lesions after fine needle aspiration. Rev Col Bras Cir. 2007 Sept/Oct;(5):4.

Saleh HA, Clayman L, Masri H. Fine needle aspiration biopsy of intraoral and oropharyngeal mass lesions. Cytojournal. 2008;5:4.

Santiago K, Rivera A, Cabaniss D, Dhurhar N, Moroz K. Fine-needle aspiration of cytomegalovirus sialadenitis in a patient with acquired immunodeficiency syndrome: pitfalls of diff-quik staining. Diagn Cytopathol. 2000 Feb;22(2):101-3.

Santos, Ana Paula Candido dos. Análise comparativa da punção aspirativa por agulha fina (PAAF) em relação a biópsia em cavidade oral e região de cabeça e pescoço [dissertação]. São Paulo: Universidade de São Paulo, Faculdade de Odontologia; 2010.

Santos AP, Sugaya NN, Pinto Junior DoS, Lemos Junior CA. Fine needle aspiration biopsy in the oral cavity and head and neck region. Braz Oral Res. 20112011 MarApr;25(2):186-91.

Saran RK, Nijhawan R, Vasishta RK, Rattan V. Desmoplastic ameloblastoma: a case report with fine-needle aspiration cytologic findings. Diagn Cytopathol. 2000 Aug;23(2):114-7.

Schelkun PM, Grundy WG. Fine-needle aspiration biopsy of head and neck lesions. J Oral Maxillofac Surg. 1991 Mar;49(3):262-7.

Sehgal S, Goyal P, Singh S, Kumar A. Fine-needle aspiration cytology of myoepithelial carcinoma of salivary gland: Diagnostic challenge to cytopathologist. J Cytol. 2013 Jul;30(3):207-10. 
Shah SB, Singer MI, Liberman E, Ljung BM. Transmucosal fine-needle aspiration diagnosis of intraoral and intrapharyngeal lesions. Laryngoscope. 1999 Aug;109(8):1232-7.

Skoog L, Pereira ST, Tani E. Fine-needle aspiration cytology and immunocytochemistry of soft-tissue tumors and osteo/chondrosarcomas of the head and neck. Diagn Cytopathol. 1999 Mar;20(3):131-6.

Stone $\mathrm{CH}$, Gaba AR, Benninger MS, Zarbo RJ. Odontogenic ghost cell tumor: a case report with cytologic findings. Diagn Cytopathol. 1998 Mar;18(3):199-203.

Tarantino DR, McHenry CR, Strickland T, Khiyami A. The role of fine-needle aspiration biopsy and flow cytometry in the evaluation of persistent neck adenopathy. Am J Surg. 1998 Nov;176(5):413-7.

Tolosa EMC. Manual de técnicas para histologia normal e patológica. $2^{\mathrm{a}}$ ed. Barueri, SP: Editora Manole Ltda; 2003.

Tsamis I, Giatromanolaki A, Tamiolakis D, Georgiou L, Manavis J, Alexiadis G, et al. Fine needle aspiration cytology in ameloblastoma of the mandible. Cytopathology. 2002 Dec;13(6):375-8.

Tyagi R, Dey P. Needle tract seeding: An avoidable complication. Diagn Cytopathol. 2014 Mar; 00(00):1-4. doi: 10.1002/dc.23137. [Epub ahead of print]

Vargas PA, da Cruz Perez DE, Mata GM, de Almeida OP, Jones AV, Gerhard R. Fine needle aspiration cytology as an additional tool in the diagnosis of odontogenic keratocyst. Cytopathology. 2007 Dec;18(6):361-6.

Wakely PE Jr., Kneisl JS. Soft tissue aspiration cytopathology. Cancer. 2000 Oct;90(5):292-8.

Wright CA, Pienaar JP, Marais BJ. Fine needle aspiration biopsy: diagnostic utility in resource-limited settings. Ann Trop Paediatr. 2008 Mar;28(1):65-70.

Wu M, Idrees M, Zhang Z, Genden E, Burstein DE. Papanicolaou stain may not be necessary in majority of head and neck fine-needle aspirations: evidence from a correlation study between Diff-Quik-based onsite diagnosis and final diagnosis in 287 head and neck fine-needle aspirations. Diagn Cytopathol. 2010 Nov;38(11):846-53.

Yang GC, Kuhel WI, Scognamiglio T. Amyloid-rich low grade adenocarcinoma of the parotid: Fine-Needle Aspiration Cytology With Histologic Correlations. Diagn Cytopathol. 2014 Feb. 
Yang GC, Waisman J. Distinguishing adenoid cystic carcinoma from cylindromatous adenomas in salivary fine-needle aspirates: the cytologic clues and their ultrastructural basis. Diagn Cytopathol. 2006 Apr;34(4):284-8.

Young JE, Archibald SD, Shier KJ. Needle aspiration cytologic biopsy in head and neck masses. Am J Surg. 1981 Oct;142(4):484-9.

Zbären P, Schär C, Hotz MA, Loosli $\mathrm{H}$. Value of fine-needle aspiration cytology of parotid gland masses. Laryngoscope. 2001 Nov;111(11 Pt 1):1989-92. 
Anexo A - Parecer do Comitê de Ética em Pesquisa da FOUSP

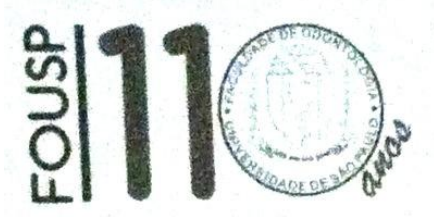

\author{
UNIVERSIDADE DE SÃO PAULO \\ FACULDADE DE ODONTOLOGIA \\ COMTtê de ÉTICA EM Pesquisa
}

\title{
PARECER DE APROVAÇÃO \\ Protocolo 61/11 \\ CAAE 0069.0.017.000-11
}

Com base em parecer de relator, o Comitê de Ética em Pesquisa APROVOU o protocolo de pesquisa "Avaliação da Punção aspirativa por agulha fina (PAAF) em cavidade oral e região de cabeça e pescoço em diferentes técnicas de coloração", de responsabilidade da Pesquisadora Ana Paula Candido dos Santos, sob orientação do Prof. Dr. Celso Augusto Lemos Júnior.

Tendo em vista a legislaçäo vigente, devem ser encaminhados a este Comitê relatórios anuais referentes ao andamento da pesquisa e ao término cópia do trabalho em "cd". Qualquer emenda do projeto original deve ser apresentada a este CEP para apreciaçăo, de forma clara e sucinta, identificando a parte do a ser modificada e suas justificativas.

São Paulo, 29 de junho de 2011.

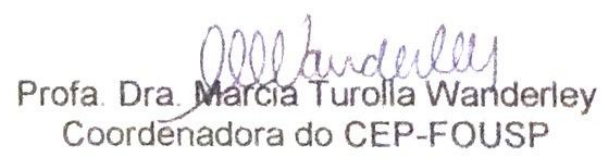

Av. Prof. Lineu Prestes, 2227 - Cidade Universitana "Armando de Salles Oiveira"

São Paulo - SP - CEP 05508-900-Tel (0XX11) 3091-7960 


\title{
Anexo B - Termo de Consentimento Livre e Esclarecido
}

\author{
管 \\ Universidade de São Paulo \\ Faculdade de Odontologia \\ Termo de Consentimento Livre e Esclarecido
}

Você está sendo convidado a participar de nossa pesquisa: Avaliação da Punção Aspirativa por Agulha Fina (PAAF) em cavidade oral e região de cabeça e pescoço em diferentes técnicas de coloração. Esse trabalho nos ajudará a utilizar um novo método de exame que facilite o diagnóstico das alterações em boca.

O exame será realizado antes que seja feita a biópsia da região em questão. O material colhido será encaminhado juntamente com o material da biópsia para o serviço de Patologia da Faculdade de Odontologia da Universidade de São Paulo (FOUSP), e os resultados serão analisados e informados ao paciente que procurou o serviço da Faculdade. Após a obtenção dos resultados, o paciente será encaminhado para o tratamento adequado da alteração que possuir.

Os riscos da pesquisa são mínimos: poderá ocorrer desconforto, dor de leve a moderada, inchaço e hematoma na região. Caso um desses riscos ocorra, o tratamento será realizado.

Você será esclarecido sobre a pesquisa em qualquer aspecto que desejar. Sendo livre para recusar-se a participar, retirar seu consentimento ou interromper a participação a qualquer momento. A sua participação é voluntária e a recusa em participar não irá acarretar qualquer penalidade ou perda de benefícios.

$\mathrm{O}(\mathrm{s})$ pesquisador(es) irá(ão) tratar a sua identidade com padrões profissionais de sigilo. Os resultados do exame clínico, laboratorial, e da pesquisa serão enviados para você e permanecerão confidenciais. Seu nome ou o material que indique a sua participação não será liberado sem a sua permissão. Você não será identificado(a) em nenhuma publicação que possa resultar deste estudo. Uma cópia deste consentimento informado será arquivada no Departamento de Estomatologia da Faculdade de Odontologia da Universidade de São Paulo.

A participação no estudo não acarretará custos para você e não será disponível nenhuma compensação financeira adicional.

$\mathrm{Eu}$

fui informado (a) dos objetivos da pesquisa acima de maneira clara e detalhada e esclareci minhas dúvidas. Sei que em qualquer momento poderei solicitar novas informações e motivar minha decisão se assim o desejar. 0 professor orientador Prof. Dr. Celso Augusto Lemos Júnior e a pesquisadora Ana Paula Candido dos Santos certificaram-me de que todos os dados desta pesquisa serão confidenciais.

Também sei que caso existam gastos adicionais, estes serão absorvidos pelo orçamento da pesquisa. Em caso de dúvidas poderei chamar a pesquisadora Ana Paula Candido dos Santos ou o professor orientador Prof. Dr. Celso Augusto Lemos Júnior no telefone (11) 3091-7813 ou o Comitê de Ética em Pesquisa (CEP) da FOUSP no telefone (11) 3091-7960 sempre que quiser obter informações. Declaro que concordo em participar desse estudo. Recebi uma cópia deste termo de consentimento livre e esclarecido e me foi dada a oportunidade de ler e esclarecer as minhas dúvidas.

\begin{tabular}{ccc}
\hline Nome & Assinatura do Participante & Data \\
\hline Nome & Assinatura do Pesquisador & Data \\
\hline Nome & Assinatura da Testemunha & Data
\end{tabular}

